\title{
NEGROES AND THEIR TREATMENT IN VIRGINIA FROII 1865 TO 1867
}

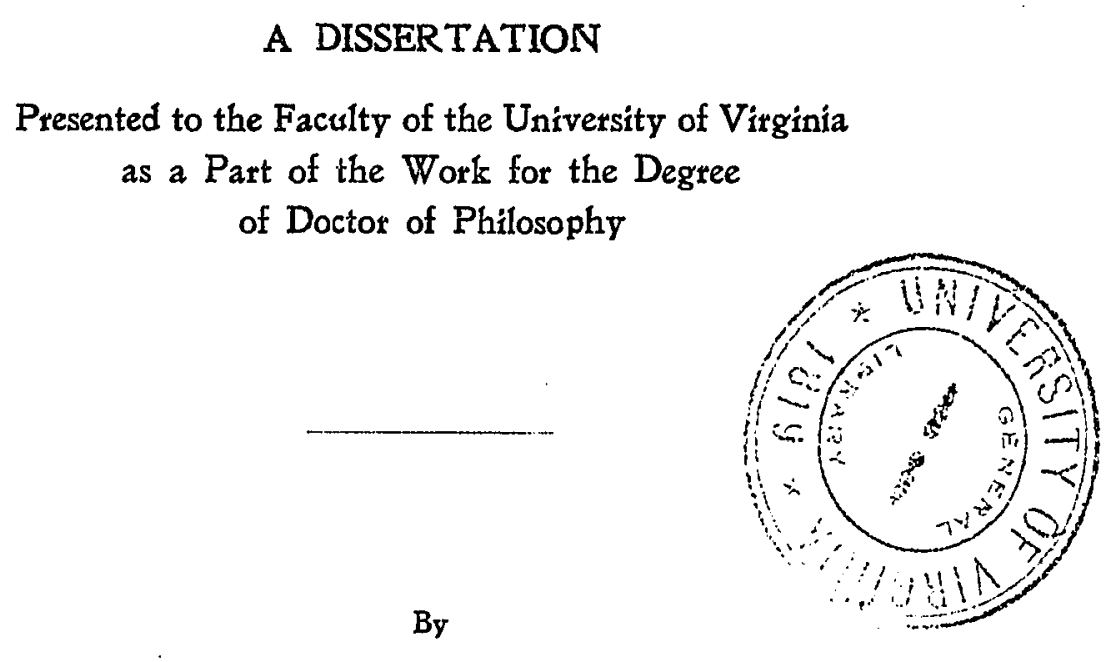

JOHN PRESTON MCCONNELL, M. A.

PTE \& BROTHERS,

Pulaski, Va. 


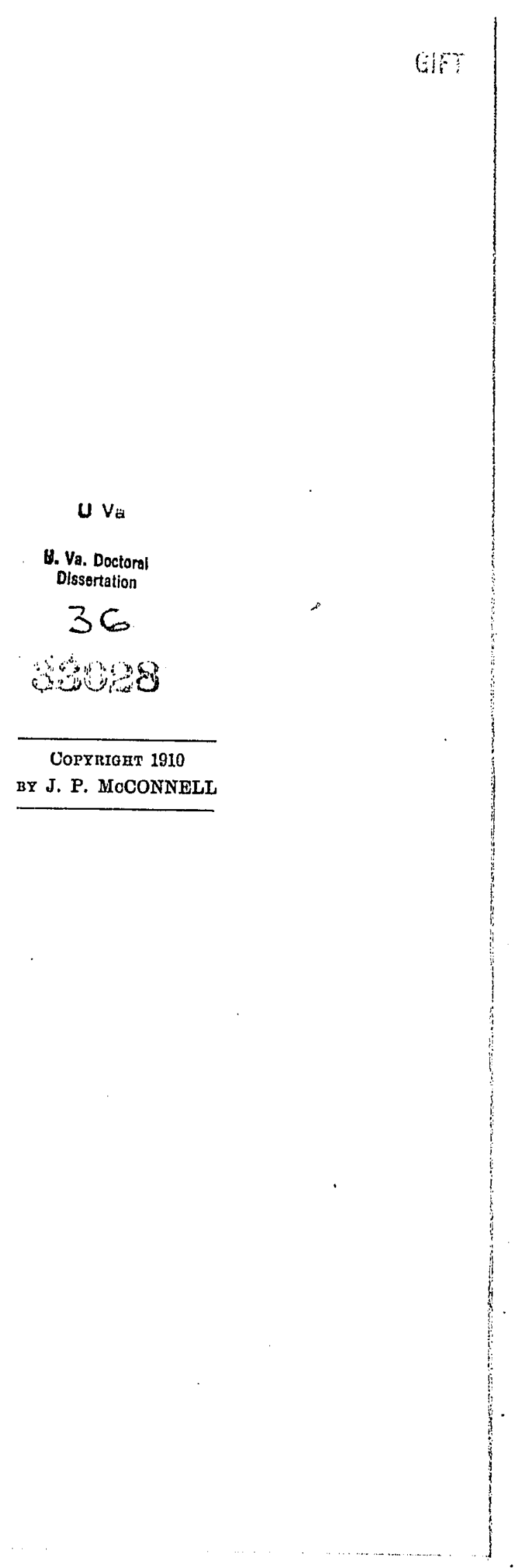




\section{TABLE OF CONTENTS.}

CHAPTER I.

Number and Distribotion of Negroes in Viratnia.

CHAPTER II.

Public Optnion in Virginia in Regard to Emaxoipation.

CHAPTER III.

The ETfeot of Emancipation on tire Negroms.

CHAPTER TV.

Disturbing Forcis.

CHAPTER $\nabla$.

- . The Evolotion of a Stgtem of Hired labor.

CHAPTER VI.

VAGRANCY aND VAGRaNOT LaWB.

CHAPTER VII.

CoNtract Laws.

CHAPTER VIII.

The Suave Code Repealed.

CHAPTER IX.

Odtrageg on Fregdmen and the Civil Codrts from 1865 to 1867.

CHAPTER X.

Framdman aNd Crvil Rights in 1865 aNd 1866.

CHAPTER XI.

Enpranchisement of the Freedmen. 
CHAPTER XII.

Eddoltion of Freedaren.

CHAYTER XIII.

APPRENTIOE LAWR.

CHAPTER XIV.

Negro Marriages.

CHAPTER XV.

INSURRECTION.

CHAPTER XVI.

Separate Chorches ror Negroes.

CHAPTER XVII.

EFfects of tee Reconstruction Acts.

CHAPTER XVIII.

Summary and Conolusion.

BIBLIOGRAPHY. 


\section{Negroes and Their Treatment in Vir- ginia from $\mathbf{1} 865$ to $\mathbf{1} 867$.}

\section{CHAPTER I.}

NuMber aND Distribution OF NegRoes IN VIRGINIA.

THE surrender of General Lee at Appomattox virtual1 Iy closed the War between the States. This contest had freed the negroes throughout the seceding States; but the future status of the freedmen had not yet been determined.

In the spring of 1865 there were probably about half a million negroes in the State of Virgivia-a number sufficiently large to prove a very disturbing factor amongst a white population of less than 700,000 . It added much to the gravity of the situation that in a large part of the State the negroes were a very small part of the population, while in other grand divisions of the State the excited and idle freedmen were in a decided majority. There are no figures giving the population of Virginia in the year 1865, yet the census reports of 1860 or 1870 will enable one to determine with considerable accuracy the distribution of the white and colored population throughout the State at the close of the war.

The census of 1870 shows, in the eighteen southwest counties of the State, a white population of 152,297 and a colored population of only 21,595 . In the twelve Valley counties having a white population of 117,321 there were only 25,681 negroes. In these two great divisions of the State, embracing thirty counties with a white population of 
269,618 , there were only 47,276 negroes who constituted less than fifteen per cent. of the entire population. ${ }^{1}$

In these two sections the greater part of the labor bad always been performed by white men as free laborers working either for themselves or for other white men for wages. Slave labor had never been such an important factor in the industry of these communities as it had been in the counties east of the Blne Ridge; for this reason, there was less disturbance of the industrial system of these sections, the whites more readily adapted themselves to a system of free labor, and the supply of labor was much less demoralized than in the parts of the State where society and industry were, in a larger degree, based on slave labor. ${ }^{2}$ Probably the negroes did not desert the farms and their accustomed trades to such an extent in these sections as they did in the eastern and southeastern parts of the State. If as large a percentage of them did leave their old homes and trades they were very readily absorbed as barbers, porters, liverymen and in other menial services about the towns.

In the section of the State east of the Blue Ridge there were, according to the census of $1870,442,471$ whites and 465,565 blacks, giving the negroes a majority over the whites of $23,044 .^{3}$ In 1860 the Southside, the counties south of the James River, had a negro population of 207,668. This population had increased considerably by $1865 .^{4}$ It is safe to say that these counties contained at least 215,000 negroes in the spring of 1865 . Here a large part of the labor had always been performed by negro slaves. In the counties of Amelia, Brunswick, Charlotte, Cumberland,

1For distribution of negroes throughout the State, see pp. 5, 69-70, Vol. of Statistics and Population, Census Report 1870.

2For demoralized state of labor and industry in the eastern part of: the State, see the Virginia newspapers of that period.

${ }^{3} \mathrm{Pp}$. 69-70, Vol. of Statistics and Population, Census Report $18 \% 0$.

This section was comparatively little disturbed by army operations until near the close of the war. 
Nottoway, Powhatan, Prince Edward, Prince George, Surry and Sussex, the negroes constituted about two-thirds of the inhabitants. In Buckingham, Lunenburg, Southampton, Dinwiddie and Halifax, the negroes were in majorities ranging from 2,000 to 7,000 in each county. In Campbell and Pittsylvania they had a majority in a combined population. ${ }^{5}$ In many other counties in eastern and southeastern Virginia the negroes were in the majority and were more ignorant than in the sections of the State where they were less numerous. As might be expected it was in these sections that the emancipation of the slaves brought most hardships and disorder.

In addition to these agglomerations of negroes in certain sections of the State, thousands of them had thronged to the cities and towns and there taken up their abode. The census of 1870 shows that the thirty-five cities and towns of the State, for which the population was given in 1860 and 1870, had an increase of only 705 white inhabitants, while the increase of the colored inhabitants in the same towns was 25,834 . This increase of colored population took place almost entirely in the section of the State where the negroes were most numerous. In many of the towns of the Valley and the Southwest there was an actual decrease in the number of negroes. In the decade from 1860 to 1870 the white population of these thirty-five towns grew from 88,381 to 89,086 . The colored population in the same cities leaped from 41,675 to 67,509 . The number of negroes in the District of Columbia had grown from 14,316 in 1860 to 43,404 in 1870, of whom 16,785 had been born in Virginia. Alexandria's colored population had in the meantime grown from 2,801 to 5,301; Hampton's from 855 to 1,841 ; Richmond's from 14,275 to 23,110; Norfolk's from 4,330 to 8,766 ; Portsmouth's from 1,477 to

${ }^{5}$ For number and character of negroes in the Southside, see passim Bruce, Plantation Negro as a Freeman. 
3,617 . There had been very little increase in the white population in any of these cities, and in Alexandria, Lynchburg, Mavchester, Petersburg, Williamsburg, Portsmouth, Fredericksburg and Winchester there had been an actual loss in the number of the whites for this same decade. ${ }^{6}$ The number of negroes in the towns and cities of Virginia in 1865 was trom twenty-five to fifty ${ }^{7}$ per cent. greater than it was in 1870 , before which time many of them had returned to the farms.

The census of 1870 shows that more than 50,000 of the negroes in Maryland, Pennsylvania, Ohio, District of Columbia, Massachusetts and New York had been born in Virginia." Many of them had gone to these states before the war, but it is not possible to determine at present how many. It is a siguificant fact that the colored population of. Virginia and West Virginia was 18,086 less in 1870 than in $1860^{\circ}$. A constant stream of negroes poured across the Potomac and Ohio rivers from 1862 to 1867. Kentucky and Missouri had also lost about the same percentage of their blacks. The number of negroes in each of the seceding States, except Virginia, was larger in 1870 than in 2860. In some of the states, in which the military operations had not been so constant, the

6Pp. 278-283, Vol. of Statistics and Population, Census Report 1870.

'This statement is based on estimates made by conservative citizens who were living at that time. The press and army offcers spoke repeatedly of the influx of negroes to the cities. Ther'e are no flgures giving the number of negroes in the towns in 1865. Gen. Halleck reported, June 25, 1865 , that there were from 30,000 to 40,000 free negroes in Richmond at that time. Serial 97, Official Records of War of Rebellion.

For account of the desertion of their homes by negroes see Richmond Dails Enquirer, May 22, 1866; The Richmond Republic, May 16, 1865, and Aug. 10, 1865. Women, with their children, walked three or four days to get away from their old homes to the towns.

8Table VI, Vol. Statistics and Population, Census Report 1870.

Table II, Ibid. See this table also for gain or loss in negro population in other states. 
increase of the negro population had been very marked, being 79,000 in Georgia and more than 30,000 in several other states. The remoteness of most of the slave states from the free states rendered "refugeeing" very difficult for all negroes and impossible for most of them. The presence of the Federal armies and the proximity of free territory rendered it comparatively easy for many negroes in Virginia to find their way across the Ohio or the Potomac to the free states.

It is, therefore, easy to see, that in the spring of 1865 the whole slave system was utterly destroyed in Virginia; the former slave population was agitated and unsettled; the old forms of industry and social life based on slavery were irrevocably gone.

\section{CHAPTER II. \\ Publio Opinion in Virginia in Regard \\ to Emanoipation.}

Although Congress, in the Crittenden Resolntion of July, 1861, had declared that the war was not waged to interfere with any of the domestic institutions of the states, but solely for the preservation of the union of the states, and that the war should cease when that union was assured, it was felt everywhere that the fate of slavery was an issue. The South had entered into the contest feeling that failure would involve the downfall of slavery. Before the war was finished it became quite as much the aim of a large part of the people of the Northern States utterly to extirpate slavery as to preserve the union. It was felt that it was 
necessary to destroy slavery to save the union. With these clearly defined issues the war was fought out.

At the close of this four years' contest, in which the people of the South with an unanimity unparalleled resisted the invading armies as long as honor demanded or humanity permitted, it was naturally asked by the world: "Do the people of Virginia accept the abolition of slavery in good faith, or is their acquiescence in its destruction only a ruse of exhausted disloyalty, by which they hope to gain strength and opportunity to renew the contest to restore slavery, or to accomplish by cunningly devised legislation the re-enslavement of the negroes? Has the war merely destroyed the name of slavery without destroying its reality?"

To appreciate just how the people of Virginia regarded the abolition of slavery it is necessary to understand what they thought of this institution prior to the war. Many slaveholders in Virginia had long considered slavery a burden on the masters and a detriment to the best interests of the community. ${ }^{1}$ It had long been a question with many of the most thoughtful whether slavery in Virginia was profitable in the mere production of wealth. Throughout the South slave labor was being driven to a few regions devoted to the cultivation of tobacco, cotton and sugar cane. Slaves were not as valuable in Virginia as in the undeveloped states of the Southwest. The average hire of an able-bodied man slave for the four states, Arkansas, Texas, Mississippi and Louisiana was in 1860 a little more than 60 per cent higher than in Virginia." As a natural

'Congressional Globe 1865-1867 (passim), debates on Freedmen's Bureau Bill, Civil Rights Bill, Constitutional amendments and Reconstruction acts. See also Summer's speech, Congressional Globe 1864-1865, p. 089. See Carl Schurz's report, Congressional Globe 1865-1866, p. 1305.

1Minor's Institutes, Vol. I, p. 168. Ballagh, A History of Slavery in Virginia.

2Annual Report of the Department of Agriculture 1867, p. 416. Vir. ginia never engaged in breeding and raising negroes for the slave market. For conclusive evidence of this see The Domestic Slave Trade by W. H. Collins. 
consequence slavery had lost much of its popnlar support in Virginia as compared with the "Cotton States;" for any community is apt to see the weakness of slavery when it has once ceased to be profitable, even if it cannot see the means of abolishing it.

The same spirit that had caused Jefferson and Henry to deplore the evils of slavery persisted in Virginia. Like Jefferson, Henry and Tucker at the beginning of the century, many owners of negroes in the middle of the century would gladly have been free from their slaves; but, embarrassed by the difficulties and dangers of emancipation and restrained by the meshes of this all-permeating institution, they did not feel justified in taking the initiative in this general manumission. The atrocities of the lately emancipated West India negroes deterred many from following their desire to liberate their own servants. In addition to all these difficulties every plantation was a little community in which there were many helpless old negroes, cripples, and children who were unable to provide for themselves. To liberate these and turn them adrift would, under the mantle of philanthropy, have been extreme heartlessness and cruelty. The white master could not feel that it was his duty to continue to care for the dependents and at the same time emancipate the able-bodied sons or fathers to lead idle and vagrant lives. The master, therefore, however humane or philanthropic he might be, was under the moral obligation to hold these plantation groups together. ${ }^{3}$

A plan of gradual emancipation was seriously discussed in the General Assembly of Virginia in 1831-324. Public sentiment was rapidly moving toward a general emancipation about the time the anti-slavery crusade began in the

'Bruce's Plantation Negro as a Freeman discusses, in an admirable manner, the economy of a Virginia slave plantation and the difticulty of breaking it up.

'Minor's Institutes, Vol, I, p. 168. 
North. The abolitionists became quite offensive in their criticism of slavery in the South. The Virginians, always jealous of outside intermeddling with their affairs, resented the efforts of Northern agitators. Naturally the movement was thus checked in the State. Nevertheless the Legislature continued to provide for emancipation and granted an annual appropriation of $\$ 30,000$ and a poll tax of one dollar per head on every male free negro of the age of twenty-one years and under fifty-five to be used in colonizing free negroes in Liberia. ${ }^{5}$ This appropriation, continued until 1860, is a proof of the sincerity of the Virginians in their professions of interest in the gradual abolition of slavery, and shows how keenly they realized the difficulties of emancipating the negroes and aliowing them to remain in the State, and further explains why so many men, who detested the whole system, hesitated to free their slaves. There were statutes against the immigration of free negroes into the State. ${ }^{6}$ The presence of negroes in any capacity was felt to be a perplexing problem of which the most practical solution was either gradual emancipation and colonization or, if this was impracticable, the continued servitude of the negroes. There had been a great amelioration in the treatment of slaves in the twenty-five years preceding the war. Many benevolent individuals exerted themselres to bring about this state of things by creating in the public mind a spirit of reprobation of cruelty to slaves.?

Gov. F. H. Pierpont, of Virginia, in his message to the Legislature in 1865, speaking of the negroes, said that their condition was a hard one as they had the "theory of the politicians and the dogma of the divines against them." His statment is true if he meant that the politicians of the State considered the negro a race so radically different from

GCode of 1860 , p. 520 .

${ }^{8}$ Code of 1860, p. 810 .

THildreth, Despotism in America (passim).

8American Annual Cyclopædia 1866, p. 763. 
the whites that it was impossible for them to be assimilated by the whites; that they were a race incapable of sharing in the government of the State; and that the wisest solution of this question for both races at that time, at least, was the political and social subordination of the weaker race to the stronger. The statement is not true if he means that the great mass of the people either in 1860 or in 1865 bore any malice or hatred to the negroes, or that they wished to make hard the condition of their lives." In regard to the statement that the dogmas of the divines were against the negroes, the great body of the ecclesiastical leaders of the State were not in love with the institution of slavery. They did not wish its presence but simply accepted it as the wisest and most humane solution of the presence of the negroes amongst the whites. They felt that the mere holding of a negro as a servant was not obviously opposed to the spirit and doctrine of the Christian religion. They were deeply interested in their spiritual welfare and carried on a successful propaganda among them with the result that a very large percentage of them were severely orthodox Christians when they became freemen in $1865 .^{\circ}$

USee State newspapers of that period in regard to the feeling toward negroes.

A letter from B. Johnson Barbour, Esq., published in The Republic, Richmond, Va., Aug. 12, 1805. * * * "In their general conduct they (the whites) should recognize the two great facts which the war has established-Life to the Nation and Death to Slavery. It is our duty to deal kindly and gently with a race suddenly emancipated, even though in the first flush of freedom they should violate our traditional ideas of subordination and discipline. By calmness and patience we shall do much toward repressing that spirit of agitation which, through folly or crime, wonld make freedom a curse instead of a blessing to the negro. His future conditiou is the only difficult problem left unsettled by the war."

oThis is the universal testimony. These facts are forcefully brought out in a personal letter from Rev. J. Wiiliam Jones to the writer.

The following preamble and resolution adopted by the East Hanover Presbytery is representative of the spirit of the other denominations:

"In consideration of the fact that the largest proportion of the colored population are within the bounds of East Hanover, this Presbytery would 
There were slaveholders who, in their heartlessness and greed for gain, made the life of the slave a burden and thus made slavery odions in the eyes of the world. It is doubtless true that some ministers were over anxious to palliate the evils and to magnify the necessity and the Christianity of slavery. Still it is true that the great body of the most thoughtful men of all classes regarded human slavery as an unfortunate inheritance, a burden from which they wished to be relieved by some safe and practicable means.

Entertaining these opinions the people of Virginia did not hesitate to accept the abolition of slavery as one of the most patent results of the contest out of which they emerged in 1865. The events and agitation of the four years' war had so shattered and demoralized slavery that all sensible men felt that its fate was sealed in Virginia, whatever might be the wishes of the whites. Large numbers of the slaves had enjoyed a taste of personal liberty within the Union lines. It was not to be expected that they, having once felt that they were free, would readily take again their former places as slaves. In the Valley, in the Northern, North Central and Tidewater counties of the State, the old plantation life was broken up. It was estimated in the spring of 1865 that 50,000 negroes in Virginia had deserted

express its undiminished interest in the spiritual welfare of this class of our people and its solemn couviction of the peculiar responsibilities now resting upon us in consequence of the new relations they now sustain to us,

"Remembering that our colored friends have an equal interest with us in the redemption provided by Christ Jesus, and mindful of the claims of those who were born and reared among us, and many of whom are still members of our families and in our employment, and regarding it both as our duty and privilege to do all in our power to promote their spiritual well-being, liesolved, That by means of family and Sabbath school and catechetical instruction, by the preaching of the Gospel for their special benefl, we will endeavor, with unabated zeal, to advance their religious culture, with the hope and prayer that we may be made equally instrumental with other denominations-our co-laborers with us -in the great work of bringing them into the fold of Christ."-Richmond Republic, Sept. 21, 1865. 
their homes and masters. ${ }^{1}$ These were generally the most intelligent and aspiring of their race-many of them being soldiers in the Federal army.

The Virginians, seeing that slavery was already "worn out by the friction of the war," had laid down their arms in 1865, understanding full well that they had seen the last of slavery; and, in their hearts, many were thankful that they were rid of it." While few recognized that it had been constitutionally abolished, most were glad to accept it as an accomplished fact and felt that the dire consequences that seemed about to follow the wholesale aud immediate emancipation, were not chargeable to them. After the close of hostilities and the return of the soldiers to their homes,

1Richmond Times, July 14, 1865.

2May 17, 1865, Richmond Times said: "The fate of slavery in Virginia was, by the nutural effects, * * settled in Virginia before the Confederacy collapsed. * * Uuder such circumstances, if the continuance of slavery was decreed tomorrow, the shattered wreck of the dilapidated carcass of the institution would prove, we fear, little better than an eyesore and a stumbling block in our path, a mildew upon our prosperity."

Richmond Enquirer, Nov. 23,1S65, says: "The abrogation of property in slaves" is one of the indisputable results of the war. The Richmond Republic, May 10, 1865, says: "The war has administered a death blow to slavery. Nothing, therefore, is more idle or vain than the bope or expectation of prolonging the existence of the institution (of slavery) by expedients which should aim to preserve the reality while relinquishing the name." However, the Daily Dispatch, Jan. 4, 1865, claims that the condition of the negro, if freed by the Federal Government, would be more pitiable than that of the slave and that a new slavery would arise. Robert Ridgeway, in The Whig, Aug. 11, 1805, says: "The abolition of slavery is one of the accomplished results of the war and it becomes the duty of the people of Virginia to accept that result in entire good faith, dismissing from their minds the chimerical idea, if any such idea is entertained by them, that it can, iv any event, ever be re-established. The Richmond papers from April, 18i5, to the close of the year, give accounts of county mass-meetings in various parts of the State, accepting unreservedly the abolition of slavery as an accomplished and irrevocable fact. The General Assembly, in its Joint Resolution of Feb. 6, 1s66, unconditionally accepted emancipation. Acts $1865-6$, p. 443 . Hon. A. H. H. Stuart's "Narrative of the Popular Movement in Virginia in 1865, and the Committee of Nine," discusses very fully the feeling in regard to the unconditional emancipation of the slaves. 
large and representative meetings of the white citizens were held throughout the State, in which resolutions were adopted declaring that the people accepted in good faith and without mental reservation the results of the war, amongst which they regarded the abolition of slavery the chief. Many of the most prominent men in the State, by speeches and open letters in the newspapers, expressed their acquiescence in emancipation and urged all the people everywhere to accommodate themselves to the changed relations they bore to their former slaves, to deal fairly with them, to employ them for wages, or to share with them the crops.

The negroes were at once recognized as free. Their right to assert their freedom was not questioned. Col. 0 . Brown, the assistant Commissioner of the Freedmen's Bureau for the State of Virginia, in his report to Gen. O. O. Howard, at the close of the year 1865, says: "It is believed that there is not within the State a person who does not understand and successfully assert his right to freedom. ${ }^{3 \prime}$ If there had been any denial of freedom to any freedman in the State it is not probable that it would have escaped the attention of Col. Brown, as the agents of the Bureau were scattered over the State and were generally careful to investigate any real or imagined wrong done a negro, and the negroes were not negligent in reporting their troubles to the Freedmen's Bureau.

In addition to the evidence furnished by the numerous county meetings, in regard to the full and frank acceptance of the freedom of the negro, the editorials and the correspondence of the representative newspapers of the State repeatedly expressed full recognition of the unconditional destruction of slavery. ${ }^{*}$ In the summer of 1865 it was reported

3Col. O. Brown's report of the operation of the Feedmen's Bureau in Virginia 1865, published in Lynchburg Virginian, Jan. 2, 1866.

${ }^{4}$ See newspapers of that period. April 25, 1865, Gen. Halleck, in letter to Secretary Stanton, quotes Alexander Rives as seying that nearly all 
that a man in Petersburg was paying. $\$ 10.00$ per capita for the claim of ownership of able-bodied negroes, in the belief that they would be remanded to their old condition. So absurd did his course seeru that he was made a subject of ridicule and held up by the press as a sort of harmless and good-natured lunatic. It was declared by the press that the restoration of slavery was not desired, even if the courts should hold the varions proclamations and acts emancipating the slaves unconstitutional. ${ }^{5}$ The following quotation from Ex-Gov. Henry A. Wise expresses about what many representative Virginians thought in the summer of 1865: 'So far from my being opposed to the name 'freedom' as indicating the condition of slaves freed by the war, the chief consolation I have in the result of the war is that slavery is forever abolished; that not only slaves are, in fact, at last freed from bondage but that I am freed from them. Long before the war ended, I had definitely made up my mind actively to advocate emancipation throughout the South. I had determined, if I could help it, my decendants should never be subject to the humiliation I have been subject to by the weakness, if not the wickedness, of slavery; and while $I$. cannot recognize as lawful and humane the violent and shocking mode in which it has been abolished, yet I accept the fact most heartily as an accomplished one, and am determined not only to abide by it and acquiesce in it, but to strive by all means in $m y$ power to make it beneficent to both races and a blessing especially to our country. I unfeiguedly rejoice at the fact, and am reconciled to many of the worse calamities of the war because I am now convinced that the war was a special providence of God, unavoidable by the nations at their ex-

parties were ready to abandon slavery and that a'popular vote would be atrongly against it. P. 989, serial 97 , Official Records of War of Rebellion. For account of delegation sent from the Legislature of Virginia to President Johnson, see p. 111, App. Congressional Globe 1865-1866.

sLynchburg Virginian, June 12, 1865, and for several days following. 
treme, to tear loose from us a black idol from which we could never have been separated by any other means than those of fire and blood, sword and sacrifice."

Col. O. Brown, the agent of the Freedmen's Bureau in Virginia, divided the people of Virginia into three classes according to their views of the negro and the Freedmen's Bureau. Of the first class he said: "Many of the citizens, under the control of tradition, habit and education, ouly sullenly acquiesced in the freedom of their former slaves." He further complained that this class regarded the colored population as necessarily and appropriately servile and unfit for freedom; that they felt that negroes were in some way responsible for the failure of the Confederacy. For this reason he thought this first class "wholly unqualified" for co-operation in the work of the Bureau.

It is true that many people accepted the abolition of slavery as an accomplished fact without recognizing the legality or justice of the manner in which it was accomplished; but even this class entertained no hope, and but little desire, of seeing its restoration attempted.

It is also true that most people in Virginia did then regard and always have regarded the negro as an inferior race and unqualified to take a leading part in the government of the State; but this opinion of his place in society did not indispose the whites to deal justly with him and to grant him all civil rights and several political rights as will be shown later:

The feeling that a race or an individual is an inferior in point of ability and power begets a sense of kindly interest and sympathy for the weaker party by the stronger rather than a desine to do wrong or

FThis letter is quoted exactly as published in the Lynchburg Virginian, Sept. 9, 1865.

7Lynchburg Virginian, Jan. 2, 1866. 
violence to the reakling. ${ }^{8}$ Such was the case in 1865 in Virginia in regard to the negroes, from whom society hoped to receive less and to whom it felt inclined to give more than it was prepared to receive from and give to the whites. The enfrauchisement of the negroes in 1867, and the efforts to place the whites under the domination of the blacks, did much to destroy the interest and sympathy which the whites had always felt for them.

Of the second class into which he divided the people, Col. Brown said: "Another class, numerically small but of the best talent, culture and influence, not only accepted the situation, but with a wise foresight and noble patriotism were ready to co-operate with the (U. S.) government for the speediest restoration of tranquility and law, and to assist the Bureau in its endeavor to bring the highest good to all classes out of the present evils."

From these quotations it is seen that co-operation or failure to co-operate with the Freedmen's Bureau in $\mathbf{1 8 6 5}$ is one of the chief marks by which Col. Brown distinguishes and classifies the people. Perhaps it was impossible for the agents of the Freedmen's Bureau at that time to understand how any white man could sincerely accept the abolition of slavery and at the same time stand aloof from the Bureau. Still, many who unreservedly recognized and accepted the complete destruction of slavery were firmly convinced that the Bureau's purpose and method, wilh the possible exception of its educational work and the support of the absolutely helpless negroes, were unwise and tended to widen the chasm between the "whites and the blacks.

8 July 7, 1865, Richmond Times says: "The collapse of the Confederacy having, as we anticipated, resulted in the overthrow of slavery, we have no wrongs to avenge at the expense of the negro. It is to our interest to make him a useful laborer, and cruelty to the emancipated slave would be just as absurd a piece of inhumanity as cruelty to a horse or an ox."

ILynchburg Virginian, Jan. 2, 1866. 
In addition to the two classes just mentioned Col. Brown declared that "a third and more numerons class, becanse forced to acknowledge the freedom of their former slaves, wished either to effect their entire removal from the State or bind them by such contracts as would allow them but little more freedom than they formerly possessed. $"$ "'

The perplexed and unsettled state of the public mind is indicated very clearly in this quotation. By some people it was felt that the whites and blacks could not live together on terms of equality. To some the only solution of this problem seemed to be a general emigration of one of the races. There was much talk of such a movement of the negroes either to some territory of the United States or to Africa. Numbers of the most intelligent colored people in the State were setting out for Liberia; others were preparing to follow." On the other hand many whites, despairing of peace and prosperity of the community, attempting to ignore racial differences and antipathies, were planning to find for themselves new homes in Mexico or in some of the Sonth American States. Wiser heads, understanding the improbability, if not the impossibility of a general emigration either of the whites or blacks, were trying to devise some plan to reorganize the social and industrial framework so suddenly revolutionized by the immediate manumission of the colored race. The press almost universally discouraged emigration schemes and urged the people to adjust themselves to the new conditions. ${ }^{1}$

"Lynchburg Virginian, Jan. 2, 1866.

${ }^{\circ} \dot{A}$ considerable number of negroes leit Lynchburg in October, 1865, for Liberia. Others were to follow. The emigrants were very unfortunate in Liberia. It was reported that some of them were eaten by cannibals. All that were able to do so returned to Virginia. Lynchburg Virginian, Oct. 10, 1865.

1For discussion of emigration schemes pro and con see the Virginia newspapers during the summer of 1865 and enrly part of 1866 . Enquirer editorial March 17,1866 , favors "diflusion of the colored population" 
While the people of Virginia thus fully accepted the logical results of the war and granted to the negro his personal freedom, they were not in 1865 or 1866 prepared to extend to him the franchise, to admit him into the jury box, to permit him to testify in cases in which white parties alone were interested, to come into the State from any other state or to intermarry with the whites. His rights in property were secured to him by the laws existing prior to 1560 , which permitted free negroes to own personal and real property. ${ }^{2}$

\section{CHAPTER III.}

The Effeut of Emancipation on the Negroes.

Early in the war negroes began to desert their masters and to seek refuge within the Federal lines. With the progress of the struggle this movement grew stronger until the proper disposal of the fleeing negroes became quite a serious problem. From the first they realized that this contest was in a large measure concerning themselves. In many a cabin the glad word was whispered that the day for the oppressed to "come up out of Egypt" was at hand. Later they heard that the iuvading hosts of the North were coming to greet them as "men and brothers."

throughout the whole country as a solution of the question, as that will give Northern people a correct idea of negroes and prevent the blunder of give Northern people a correct idea of negroes and p
equality in the South by Congressional interference.

2For the status of free negroes before the war, see Code of 1860 ; Ballagh, $A$ History of Slavery in Virginia (passim).

sFor a full account of negro refugees and the disposal of them by the Federal euthorities, seo (passim) McCarthy, "Lincoln's Plan of Reconstruction." 
Most of the slaves remained at home until the close of the war and performed their usual tasks. The old routine of the plantation life was on the surface little disturbed. They continued to plant and to harvest the crops, to care for and protect the wives and children of their masters, most of whom were in the Confederate army. From the first to the last Virginia was the battleground of the war. From first Manassas to Appomattox it felt the mightiest shocks of the conflict. The Valley, Northern Virginia and the Tidewater were overrun by the contending armies. By the attrition of the contest slavery was worn out in these parts of the State. Even in these sections most of the slaves remained with their masters, but slavery as a vital institution was gone. In a large part of the State the negroes remained on the farms only because they did not know what else to do, not because they did not renlize that slavery was dead." So effective had been the war, the movement of the armies, and the dissemination of hope and of opinions favorable to freedom, that in the summer of 1864 the number of negroes practically free was estimated by the North American Review at 1,300,000 in the seceding States. ${ }^{5}$ Of this number Virginia had her proportional share. Jefferson Davis at the same time placed the number of negroes practically free at $3,000,000 .^{5}$ This agitation by the year 1865 had shattered the old plantation life; its vitality was gone.

From 1862 to 1865 the stream of negroes deserting their families and homes had constantly grown stronger. At Washington, Alexandria, Fredericksburg, Portsmouth, Newport News and Norfolk, they -were assembled and fed by the Federal Government. This movement was most marked in the sections of the State in which the negroes had been most frequently brought in contact with the

4For the condition of the old plantation life ịn the spring and summer of 1865, see newspapers of that period.

5P. 387, American Annual Cyclopædia, 1864, 
Union armies. In the counties of the Southside, however, and in the Southwest, almost every negro remained on his master's farm until the close of the war. On the approach of the Federal army many whites fled, taking with them their slaves; in this way the plantation life was broken up and negroes were congregated in certain places.

At the close of hostilities in Virginia the stream of freedmen pouring towards the towns and the military posts was swollen to a river. Richmond, Petersburg, Lynchburg and all the larger towns of the State were crowded with homeless and penniless negroes. The number of negroes in Richmond in the summer of 1865 was estimated at 30,000 , which indicated that at least 15,000 strange negroes were in the city. Squalid villages of freedmen grew up at the various towns along the Chesapeake Bay, at Alexandria, at Arlington, and at numerous other points throughout the State. Still the movement of the negroes was from the country to the city. So serious had the matter become that the Federal authorities issued order after order urging the freedmen to remain on the farms. At last military orders positively forbade negroes to leave the communities where they were unless it was absolutely impossible for them to find work there. 'These orders doubtless deterred many from moving to the towns. ${ }^{6}$

The increase of the negro population was especially marked in the cities held directly by the military authorities, because the negroes there expected to be fed by Fed-

6 For facts in regard to the movement of the freedmen, see Official Records of War of Rebellion, serial 97, pp. 647, 932, 833, 1005, 1086, 1150, 1185, 1186, 1288, 1296; Richmond Times, July 14, 1865; Charlottesville Chronicle, Feb. 2S, 1867; Waddell, History of Augusta County, pp. 335341 ; Bruce, Plantation Negro as a Freeman, pp. 176, 177; Richmond Times, July 14, 1865; Lynchburg Virginian, Sept. 7, 1865; Messages and Documents of the U. S. Government, 1866-1867, p. 668; Col. O. Brown's report, Lynchburg Virginian, Jan. 2, 1866; Order of Col. J. Shaw, Jr., Richmond Times, Aug. 8, 1865; Gen. Gregg's General Order No. 15, Lynchburg Virginian, June 1, 1865; Daily Enquirer, March 22, 1866, April 18, 1867; Republic, Aug. 10, 1865. 
eral quartermasters or agents of the Freedmen's Bureau. Many of them doubtless felt that their newly found freedom was too good to be true, and were fearful that they should again be remanded to slavery, unless protected by the agents of the United States Government, which they felt had secured for them the liberty which they enjoyed. Many of all classes were drawn away from their old homes and trades to the idleness and vice of the cities, yet most of the deserters were able-bodied young negroes who left their old, young and helpless behind as a burden on their former owners. In their new places of abode they were very ready to forget their wives whom chey had left behiud and contract new matrimonial obligations without much appreciation of the sanctity of this relation. The negro women especially, freed from the discipline of the old life, often became very dissolute. ${ }^{7}$

In some cases the former owners were expected to care for the belpless freedmen. The Federal authorities, however, usually recognized that the burden of supporting dependent negroes was no longer properly chargeable to their former owners, but had been shifted to the relatives of the paupers, to the community, or to the Federal Gorernment. It must be said, however, that many of these deserted untortunates were cheerfully supported by their old masters on account of affection and humanity. ${ }^{8}$

A great restlessness to get off the farms where they had been held as slaves seized almost all negroes everywhere, but some faithful slaves refused to leave their old homes and continued to live with their former masters and serve them till death.

7For effect of emancipation on the marriage relations and morals of the negroes, see Rufln, The Negro as a Political and Social Factor. (passim); Bruce, The Plantation Negro as a Ereeman, chap. II; Gen. Hallecls's report, Offcial Records of the War of the Rebellion, serial 97, p. 1296.

8Richmond Times, July 7, 1865; General Order No. 13, Lynchburg Virginian, June 2, 1865; Official Records of Wạr ợ Rebellịon, serial 47, pp. १32, 933. 
It was estimated, in July, 1865 , that at least 50,000 able-bodied negroes had deserted their helpless ones and gone to the cities of Virginia or the North. Not only had able-bodied negroes flocked to the towns and military posts, but many helpless old men, women and children were huddled together in wretched hovels. In some instances thirty negroes were, in the summer of 1865 , occupying the rooms formerly considered barely comfortable for two. In filthy improvised huts around the various military posts and in the freedmen's towns the mortality of the negroes was appalling. ${ }^{9}$

It was felt by some of the Federal army officers that there was danger of "the land going to waste" on account of the desertion of the laboring population. They proposed to treat as "vagabonds" the freedmen who were away from their old homes and without employment. ${ }^{\circ}$ Prior to the war it had been claimed that the effects of treedom on the free negroes in Virginia had been disastrous, "the successive censuses, particularly from 1840 to 1860 , showing a great physical and moral deterioration on the part of the free blacks whether compared with the

9Lynchburg Virginian, Jan. 2, 1865; Richmond Times, June 27, July 3, 7, 1865; Messages und Documents of U. S. Goverament, 1866-7, p. 668, 1888-9, p. 508; Offlcial Records of War of Rebellion, p. 1215, serial 97; American Annual Cyclopædia, 1865, p. 376.

The Whig, Oct. 2, 1866, refers to a "hallucination" amongst the negroes that the great mortality amongst them was not due to disease but poison. In the lidewater region they were living largely on melons, stale flsh and cabbage but believed in many places that the white people had "tricked" them. 'Ihey were treated by quack negro doctors with decoctions of herbs, etc. They would not trust white doctors. Nor. 5, 1866 , the same newspaper declares that the number of negroes was greatly diminished. In the Enquirer, Nov. 15, 1865, it is claimed that fifty per cent. of the negroes had perished from disease. The mortality of the negroes was not as great as it was believed to be at the time.

OSee orders regarding negroes, Official Records of the War of Rebellion, serial 97, pp. 1005, 1086, 1178, 1291; Order of Gen. Gregg, published in Lynchburg Virginian, June 1, 1865. 
slaves or with the whites." In 1865 the negroes seemed to be rapidly becoming a race of vagrants and idlers. Negroes possess a remarkably strong and persistent local attachment; yet they were so anxious to assert their liberty and to convince themselves that they were really free, that they felt in most cases that it was necessary to desert the farms where they had been held as slaves and to seek homes with some neighboring farmer, even if they did not have the courage or think it necessary to leave the entire community. Many of the largest farms were almost depopulated of their former negroes, and their places were filled either by those who had come in from a distance or from the neighboring plantations.? Fidelity and timidity influenced some to remain with their former masters but their number was not large. A vast majority of the negroes changed their habitations immediately after the war or within the next three years.

In their new homes they frequently were not able to find, even when they wished it, the forms of labor to which they had been trained. As has been mentioned before, the plantations were little industrial communities in which the division of labor system was necessarily adopted to a considerable extent. Some of the slaves were house servants and personal attendants of their masters; others were taught to spin and weave; others were blacksmiths, harness makers and carpenters; the great body of the slaves were mere field hands. When the old plantation life was broken up these freedmen were very poorly prepared for the new society in which they must compete with the white mechanics and laborers who had been trained in more lines of work as well as to a higher degree of skill in the mechanical trades. By these white competitors their employment was rendered more difficult and uncertain. This had a

1Minor's Institutes, Vol. I, p. 168.

2Bruce, Plantation Negro as a Freeman, chap. XII. 
tendency still further to demoralize the negroes and force them to drift from place to place. It is needless to say that most plantation negroes found themselves out of place in the cities, where there was not a great demand for such a large body of absolutely unskilled laborers as flocked to them in 1865 and $1866 .{ }^{3}$

\section{CHAPTER IV.}

\section{DISTURIBING ForCES.}

During the two years from the spring of 1865 to the passage of the Reconstruction Acts in March, 1867, the negroes fell largely under the influence of their preachers and a class of native whites who acted as leaders and advisers to the freedmen. The so-called "scalawags," in many instances, had been known for their cruelty and injustice to the negroes. Many of them had been slave overseers, some of them slave owners before the war; yet this reputation did not appear to be any obstacle to their winning the confidence of the freedmen. ${ }^{4}$ By artful insinuation they won the favor of the colored people, and in a large degree succeeded in alienating them from their old friends and masters. The motives of this class were entirely selfish and their influence wholly disorganizing and demoralizing at a time when society, revolutionized by the

3See the newspapers of that period for the demoralized state of labor.

II was alleged that Rer. Mr. Hunnicut, the most influantial "scalawag" in the early Reconstruction days, had been cruel to slaves before the war. 
events of the war and by emancipation, called for co-operation and confidence in all classes.

Another class, numerically very small, was made up of whites who had come to the State as agents of the Freedmen's Bureau, teachers or adventurers. ${ }^{5}$ The motives of almost all the teachers and of many of the Bureau agents were unselfish; yet their presence and the ideas nost of them entertained in regard to the place of the negro disposed most of the blacks to become dissatisfied with their position as mere "free negroes."

Many of the teachers had come from the original abolition homes of the North and were thoroughly indoctrinated with the idea of the equality of all men. They called on the negroes and extended to them other social courtesies that shocked the whites and encouraged the freedmen to demand equal privileges from all the whites; but it is untrue that they farored "miscegenation" except in rare instances. Most of them were pure and self-denying women who looked upon their work as a call from God and regarded all human beings as entitled to equal rights before the law and in society. Yet, despite the best of intentions, the teachers by their radical ideas did much to create and foster in the freedmell an aversion to taking up their old familiar labor with the shovel and the hoe. They preferred to speculate about their abstract rights rather than to avail themselves of the privileges actually before them. ${ }^{\circ}$

The Freedmen's Court, consisting of three judges, one representing the whites; the second, the blacks; the third, the United States Government, did much to keep the negroes agitated and expectant. Many of these courts gave a

5For baneful influence of clerical adventurers and redicals, see Whig, Sept. 6, Sept. 12, 1866, Feb. 4, May 11, 1867; Dispatch, May 13, 1867; Documentary History of Reconstruction (passim), edited by W. L. Fleming.

6 About this time the negroes began to talk a great deal of their desire to be "treated as a man and a brother." 
ready ear to all the complaints of the negroes, however worthless. On the information of mere negro children, aged and respectable citizens were notified to appear before these courts to inswer for the most trivial offeuses. The records of these courts show many surprising verdicts. The court at Lynchburg ordered the defendant to pay a colored freedwoman one dollar and fifty cents for "cross and unjust conduct."7 It was reported by Gen. Fullerton, who had been sent by President Johnson ov a tour of inspection throughout the South, that in Virginia "these agents take the widest latitude in the exercise of their judicial functions, trying questions involving title to real estate, contracts, crimes and even actions affecting the marital relations. We witnessed the trial of a divorce case before the sub-agent at Charlottesville. The trial occupied about ten ninutes and resulted in a decree of divorce. In many places where the agents are not men of capacity and integrity a very unsatisfactory condition of affairs prevails. This originates in the arbitrary, unnecessary and offensive interference of the agents of the Bureau with the relation between planters and their hired freedmen, causing vexatious delays in the prosecution of labor, and imposing expenses and costs in suits before themselves about trivial matters. The effects produced by the actions of this class of agents is bitterness and antagonism between the whites and the freedmen and expectations on the part of the freedmen that can never be realized."

The friends of the Bureau strenuously insisted that the Bureau courts were absolutely necessary to secure anything like justice for the negroes; that the antagonism between the whites and the blacks was not the result of the presence of the Bureau agents; and that the disturbed state of society existed, not because of the Bureau, but in spite of it.

TLynchburg Virginian, Jan. 2, 1868.

8Pp. 64-66, House Document No. 120, 1st Ses. 39th Congress. 
The object of the Bureau was to protect the interests of the colored people in the courts, in contracts and in every relation of life." Doubtless it did accomplish its purpose, in part, at least; yet the Bureau had a tendency to proloug the period of trausition from slavery to freedom by keeping the negroes in a state of excitement, since they looked upon the Bureau as a visible demonstration of the power and purpose of the United States Government from which they had already received their freedom, and from which they were led by many agents of the Bureau to believe that they had not yet received half of the good things

9Compare the mild Freednen's Bureau Bill of March 8, 1865, (p. 141, App. Congressional Globe, 1864-1865), with the drastic Bureau Bill of July 16, 1866, (pp. 366-367, App. Congressional Globe, 1865, 1866).

Negro refugees flocked to the Union army during the war. Some of them were put to work on forts and fortiflcations, others were concentrated in camps and colonies under army officers, usually chaplains. The Freedmen's Bureau, with Gen. 0. O. Howard at its head, was put in control of all negroes. The Burear was practically independent of the military and civil governments in the South.

"Its principal legal activities were relief work, education, regulation of labor, and the administration of justice." * * * * "It regulated contracts, wages, hours, rations, clothing and quarters." * * * In all that related to labor the Bureau was supreme. "The Bureau courts had jurisdiction over all cases that arose between blacks or between blacks and whites." It "supervised the civil courts, from which cases relating to negroes were often removed and the decisions of which were set aside." * * * *

"The income of the Bureau was derived from the sale of confiscated Confederate and private property, from fees, rents, taxes, county funds, gifts from individuals and associations, and from appropriations by Congress. * * * In the great majority of the black communities there was, at the end of the war, no destitution and had the negroes stayed at home and worked there would bave been little want, but the distribution of rations caused them to crowd in to the towns, and much suffering and disease resulted. In the later years of the Bureau rations were used simply as a means of organizing a black political party. The labor regalations were as a rule good in theory but absurd in practice. * * * * The education given the negro was not suited to his needs and the doctrines of social and political equality taught in some of the schools aroused the opposition of the whites. The negroes as often as the whites were cheated and blackmailed by the agents of the Bureau." Fleming, Documents Relating to Reconstruction. 
in store for them. This feeling rendered many negroes unwilling to labor. They preferred to do as little work as possible and to wait for the abasement of the whites and their own exaltation.

The number of white adventurers in Virginia from 1865 to 1867 was not large. In fact, this class was never numerous in Virginia. From the close of the war to the passage of the Reconstruction Acts in March, 1867, a considerable number of white people, it is impossible to determine how many, had come to Virginia in an unofficial capacity. Some of these had come to cast in their fortunes with the State and to assist in its development. Others had come as mere adventurers hoping to profit by the prostration and the disorganization of society without rendering any equivalent. This last class found the negroes the readiest road to influence and to wealth. They disseminated amongst the credulous blacks alluring reports of what was being done for them in the North. ${ }^{0}$

The Union League, a secret society in the interest of the Republican party, was organized throughout the State in $1866 .^{1}$ Its purpose was to attach the negroes firmly to

"The "scalawags" and "carpetbaggers" were not so influential in 1865 and 1866 as they were after the passage of the Reconstruction Acts in March, 186\%. The character and influence of the "scalawags" and "carpetbaggers" are faitufully portrayed in Thomas Nelson Page's novel, "Red Rock."

It. is perhaps impossible to determine when Leagues were first organized in Virginia. It was probably as early as 1865. The League wes gen. erally organized throughont the State in the fall and winter of 1806 and the spring of 1867. It was organized in Obio in 186\%. After the war the League favored negro suffrage and radical measures in the South. The Philadelphia League sent out more than $4,000,000$ pamphlets in three years after the war. The publications of the League largely consisted in stories of outrages upon freedmen in the Bouth. It sent teachers to the South and strope to promote the interests of the freedmen. The League was originally composed of whites. About the time the negroes were enfranchised by Congressional acts negroes were admitted in large numbers. Thereupon most of the whites withdrew leaving the control of the organization to the "scalawags," "carpetbaggers" and the negro leaders. 
the Republican party and to the organizers of the League. It was made up of negroes, "scalawags" and "carpetbag. gers." It had a large number of offices to which the colored members eagerly aspired. It held nocturnal meetings in which the colored people were urged to "stand by the Union," which they understood as meaning to stand by the Republican party and to oppose the great mass of whites in the community. The leaders of these meetings were the negro preachers, the "scalawags" and an occasional "carpetbagger." The appointment of the Committee on Reconstruction, the Congressional discussion of the Freedmen's Bureau Bill, the Civil Rights Bill and other matters touching the negroes gave an ever-quickening interest in the political discussions of the League. ${ }^{2}$

At this time the colored clergy became in a large degree the political leaders of their people. ${ }^{3}$ They were sent as delegates to the numerous conventions called by the negroes or "scalawags." They were the chief speakers on all occasions. They wrote letters to the newspapers in the State and in the North, urging their claims and declaring their grievances. They wished negroes to be admitted to

Every negro was considered a member by virtue of his color. At the weokly meetings generally held in negro churches and school houses inflammatory speeches promising confiscation of property and sociel equality were made by white and black leaders. The $W$ hig calls the Leagues "only mischief hatching concerns and nuisances." This was the general opinion of the majority of the whites.

2The facts above in regard to the object of the League, its officers and its methods were obtained from colored men who were members of the League. For Constitution and Ritual of the Leagne, see Union League Documents, edited by W. L. Fleming, University of West Virginia.

3The great body of the negroes were unable to read the newspapers. They derived about all their information from the public speakers; most of these orators were vegro preachers. See Ruffln, The Negro as a Social and Political Factor.

In a convention of Freedmen at Alexandria, Aug, 2, 1865, the preachers were present in great numbers. One of them said: "I look on this convention as the brains of Virginia."-The Republic, Aug. 4, 1885. 
the State University on the same terms as whites; they insisted on being called "Mister;" they soon declared that nothing short of absolute equality with the whites in all things would satisfy them." The League, the negro preachers, and the "scalawags" had prepared the minds of the blacks for the Reconstruction Acts of 1867. After the passage of these bills these adveuturers seized control of the State for several years.

The aforesaid disturbing forces and the undetermined status of the freedmen kept the negroes agitated, the labor supply uncertain, and labor contracts insecure. Consequently the freedmen were dissatisfied and restless; industry was languishing; vagrancy was prevalent; colored children were unprovided for, many of the youth of the land were growing up is idleness and crime.

\section{CHAPTER V.}

\section{The Evolution of a System of Hired Labor.}

The emancipation of the slaves broke up the old industries in a large part of Virginia. For more than two hundred years the people in the oldest and most populous parts of the State had been accustomed to slave labor with all its attendant circumstances and consequences. Many of the people had little or no knowledge of free labor and how to deal with it. They had little bope that their former

${ }^{5}$ A convention composed of 160 negroes and 50 whites met in Richmond April 17, 1867. One of the resolutions of this convention made great promises to poor laboring white men, in order to win their support against the "rapacious and arrogant" as they styled the whites of the State. P. 758, American Annual Cjclopædia, 1867. 
slaves would serve them faithfully or efficiently for wages. It has already been shown how the negroes, excited and agitated by their sudden liberty, were leaving the old plantation.

The Freedmeu's Bureau, in the spring and summer of 1865, was being organized throughout the State to look after the interests of the colored people. Federal soldiers were posted at all the prominent points in the State. ${ }^{6}$ It was an additional source of weakness and embarrassment that the State government at Richmond had fallen with the Confederacy in the spring of 1865 . The "restored government" of Virginia at Alexandria and later at Richmond was without much respect or popular support. The county governments were therefore unable to take vigorous measures either in punishing vagrancy and crime or in reorganizing the community. All initiative in restoring society to its normal estate was discouraged if nct positively prohibited. The white people were kept in suspense in regard to the future policy of the Federal Government. The Civil Riglits Bill and Negro Suffrage were beginning to be discussed by some of the leaders of Northern public opinion.

The outlook was gloomy. Something had to be done at once, or famine would soon stalk through the land. The planting season was far advanced in Virginia when hostilities closed in the spring of 1865 . Light crops were planted, but it seemed that it was going to be impossible to have them cultivated or harvested for lack of laborers in many parts of the State where the negroes were the chief farn hands.

Many of the planters at once agreed to give the negroes board and a share in the crops that they had already helped to plast, on the condition that they continue ou the farms and assist in cultivating and harvesting them. Not a fow

'Soldiers were posted at ten points in May, 1866. House Document: No. 120, 1st Ses. 39th Congress. 
freedmen accepted these terms. This plan seems to have met the approbation of the most prudent of the military commanders, and orders were issued from time to time urging the planters to adopt such a policy and the negroes to accept such terms. The negroes accepting these terms left their old masters and homes about the middle of the winter of 1865-66, when they had received their share of the crop, which they generally felt was too small.

The farmers of Virginia feared that the negroes as freedmen could never be induced to become faithful and regular laborers. In 1865 it seemed that a large number, if not nearly all of them, would soon become worthless and possibly as turbulent as the free negroes of the West Indies. In reality, emancipation was attended by less permanent idleness and disorganization of labor than was expected, because the discipline and habits of labor which slavery had taught the negro came to his relief when he later found that he had to work or starve. The climatic conditions of Virginia rendered it impossible for them to become permanent idlers and live as they could, and probably would have lived had they heen favored by a tropical climate and easy conditions of life such as Hayti affords. However that may be, when the alternative of work or starvation was squarely presented, most of them chose work. ${ }^{7}$

Perhaps it is easy to exaggerate the actual disorganization of labor that really did take place in 1865. The strangeness of the situation demoralized the whites quite as much as the blacks. As has already been said, the planters in a large part of the State were unfamiliar with free common labor, its dignity and its employment. ${ }^{8}$ At the same time the late slaves had much to learn of their

7Bruce's Plantation Negro as a Freeman, discusses (passim) the effect of emancipation on the industry of the negroes.

SIt was the opinion of Col. O. Brown and other Burenu agents that this unfamiliarity with free labor greatly increased the difficulties of 
true position, their rights and duties as free laborers. These conditions rendered the solution of the problems of 1865-66 still more difficult.

So despondent were many in regard to the negro as a free laborer that they thought it would be necessary to call in white laborers to take his place. White immigrants were earnestly sought; immigration societies were formed throughout the State; numerous enterprises encouraging white immigration were chartered by the Legislature during the session of 1S65-66;" a State Commissioner of Immigration was appointed. It was openly arowed that it was their purpose to induce white men to come to Virginia from England, Scotland, Germany, Poland or any other European country to take the place of the colored laborers. This was not through any hostility to the negro as a man or as a laborer, for the Virginians have always preferred the colored laborer to any other; but it arose from a belief that the freedman conld not be induced to work. In the State Farmers' Convention held in Richmond in November, '1866, to discuss the labor situation, it was declared that it was "impracticable to depend on the present labor supply;" that white labor was cheaper at high wages than colored labor at lower wages. Still it was felt by the Convention that the number of whites that could be induced to come to Virginia would be very inadequate to the demand. ${ }^{0}$

emancipation. See Col. Brown's report in Lynchburg Virginian, Jan. 2 1866.

For opinion of the freedmen as free laborers, see Whig, Jan. 3, 1866; Jan. 10, 1866; Fob. 19, 1866; April 16, 1866; Sept. 11, 1866; Enquirer, Nov. 1, 1865: Nov. 2, 1865; Nov. 5, 1865; Nov. 17, 1865; June 22, 1866; Dispatch, July 8, 1867. General Howard expresses confidence that the negro free laborer will be successful aud insists that the right of negroes to rent or buy land shall be guaranteed to them. He also thinks that joint stock companies to help poor blacks should be formed. Enquirer, Dec. 22, 1865.

'Acts 186ī-66, pp. 234-236, 287, 288, 299, 290, 203, 296-298. Richmond Times, Aug. 3, 1865; Whig, Nov. 8, 1866; Enquirer, July 11, 1866.

OLynchburg Virginian, Nov. 24, 1866. 
The number of white immigrants to Virginia during the period from 1865 to 1867 was inconsiderable. Most of those who did come to the State did not come as laborers but rather as capitalists or "carpetbaggers." It was clear to most people from the first that the negroes would in a large part of the state continue to be the chief laborers for many years and that some plan of utilizing their labor had to be devised.

Various plans were, during the summer of 1865 , proposed by the whites for the employment of the negroes. The Freedmen's Bureau had declined to fix a wage, but thought it best to leave the rate of wages to the law of supply and demand. ${ }^{1}$ The aim of the Bureau was simply to secure freedom of contract for the freedmen and to enforce the contracts when made.

One attempted solution of this question was for the farmers to hold county or district meetings to determine the rate of wages they would pay the negroes. These meetings were held in wany of the counties where the negroes were numerons. The wage agreed upon was usually $\$ 5.00$ per month and board for able-bodied men, and $\$ 3.00$ per month and board for women and boys. ${ }^{2}$ The farmers, in some instances, agreed in these county meetings not to employ negroes at any price unless they were able to furnish testimonials or recommendations from their last employer, which practically meant that a negro could not find employment unless he had the endorsement of his former owner. ${ }^{3}$

IGen. Howard's report, p. 644, Messages and Documents of U. S. Gorernment, 1866-67.

2Richmond Times, June 15, 1865, June 20, 1865; Col. O. Brown's report, Lynchburg Virginian, Jau. 2, 1866. Pp. 517, 908, GIobe, 1865-66, gives an account of a meeting of Hanover county farmers. General Young's report, p. 1158, serial No. 97, Official Records of the War of the Rebellion, also Carl Schurz's opinion, p. 1305; Glohe, 1865-66; The Republic, May 19, 1865, June 3,1865 ; Whig, Sept. $18,1866$.

35ee Richmond Times, June 20, 1865, for account of such a meeting and resolutions in Dinwiddie county. Col. Brown's report, Lynchburg Virginian, Jan. 2, 1866. 
Small as these wages seem, it does not appear that they were unsatisfactory to the negroes in some of the counties where they had been agreed upon. Indeed in some parts of the State the freedmen were glad enough to work for their board, at this time. ${ }^{4}$ In other counties the demand for colored laborers was rather active at $\$ 12.00$ per month. ${ }^{5}$

July 24,1865 , the Franklin county farmers in a meeting declared: "Whilst we recognize the propriety and necessity of giving employment to the negroes and of encouraging them to industry and good conduct by fair and reasonable rewards for their labor, still, in consequence of the many difficulties surrounding the subject, we deem it wholly impracticable at this time to fix any regular standard of wages for labor-each case must necessarily be governed by the circumstances attending it, and in the present unsettled and prostrated condition of the finances and business of the country, laborers must be content with moderate wages or go without employment."

The small wage fund and the uncertainty of the times in many parts of Virginia in 1864 and 1866 undoubtedly rendered liberal wages impossible. Col. Brown, Assistant Commissioner of the Freedmen's Burean in Virginia, said on this subject: "Stripped to a great extent of ready resources by the operations of the war they were unable to allow those people (the negroes) their just due, much less charitable assistance." ${ }^{\prime 7}$ Elsewhere he explained the low

1Richmond Times, June 27, 1865, said such was the case in Orange, Culpeper and Fauquier counties. See Peyton's History of Augusta County, p. 240.

In the Valley counties the demand for laborers at $\$ 12$ per month as farm hands exceeded the supply. House Document No. 120, 1st Ses. 39th Congress,

6Lynchburg Virginian, July 24, 1865. See Whig, Aug. 18, 1865, for account of such meetings.

Tynchburg Virginian, Jan. 2, 1866; Agrioultural Repart, 1865-66, pp. 135-136. 
wages prevailing in Virginia as the result of an excessive supply of laborers with a small demand. He suggested as the only solution, the emigration of at least 50,000 negroes from the State. ${ }^{8}$ It is asserted that the wages paid unskilled white and black laborers were practically the same at that time and the low wage paid the negroes was in no sense an effort to wrong them or to discriminate against them. Nevertheless it was generally felt by the negroes and by the Federal officers that the purpose of these county meetings was inimical to the interests of the colored laborers. The military officers generally disapproved the proceedings of these farmer meetings on the ground that "the citizens will not be permitted to band themselves together for the purpose of agreeing on any certain remuneration for the labor of the freedmen, that being in the hands of the Freedmen's Burean-the officers of which alone will decide in these matters." It has already been mentimed that the Bureau always declined to fix a wage, but strove to secure for the contracting wegro such wages as "supply and demand would insure."

In one county at least a meeting of farmers, besides fixing the wage at $\$ 5.00$ per month, resolved that no laud should be rented to negroes." These meetiugs and resolutions of the planters were regarded by many friends of the negroes as efforts to keep the colored people a landless and moneyless class whose condition was, in reality, worse than the old form of chattel slavery from which they had just emerged, while it secured to the whites the benefits of slavery without its inconveniences. It is doubtless true that a considerable number of people had consciously or

${ }^{8}$ Col. O. Brown's report for 1865 , printed in Lynchburg Virginian, Jan. 2, 1866

'District Commander's General Order printed in Lynchburg Virginian, July $27,1865$.

0isuch was the case in Amberst County. Richmond Times, June 15, 1865; Col. Brown's report, Lynchburg Virginian, Jan. 2, 1866. 
unconsciously such an object in view. Many of the people . felt that the negro was hopelessly servile by nature; that all efforts to elevate him must prove futile. Entertaining such opinions, they were ready to assent to a system of wages that would keep him in the place in society to which he was, in their opinion, suited. Yet almost all people frankly and fully accepted the unconditional abolition of slavery and wished to devise some system of lahor and contract that would secure the rights of both whites and blacks. Some of the newspapers condemned the efforts of the planters to fix wages at $\$ 5.00$ per month, declaring that such wages were not sufficient to support the laborers. ${ }^{1}$

Notwithstanding the idleness and vagrancy of the negroes during the years 1865 and 1866 it was hoped by many that they would settle down to something like their old industry when the novelty of their condition wore off and they found themselves face to face with the stern realities a free man must meet and conquer, or perish. How to put the negroes to work in this transitional period and thus prevent a great scarcity of food, if not a famine, was the question that had to be solved.

Many things disinclined the negroes earnestly to go to work on the farms at their old occupations. In the minds of most of them freedom and idleness were synonymous. Labor was a badge of servitude. If they must work, they did not wish to resume their old forms of agricultural labor; they preferred light and transient jobs about the towns, and in this way eked out a wretched support.?

The army officers stationed in Virginia during this period uniformly strove to impress the colored people with the true nature of freedom, and informed them that it

1Lynchburg Virginian, Dec. 30, 1865, June 12, 1865; Richmond Times, Aug. 3, May 19, 1865.

2For idleness of negroes and their apersion to farm labor, see newspapers of $1865-66$. 
would be necessary for them to work as hard, if not harder, than when they were slaves. Repeatedly these officers issued orders urging them to find work where they were needed and not to hope vain things from freedom. They were urged to go to work on the "abandoned" lands then in the hands of the officers of the Federal Government." On the peninsula between Fortress Monroe and Williamsburg, it is said, sixteen thousand negroes were occupying lands that the United States Government had seized." At various points throughout the State county farms were established for them where they were furnished food until they could raise a crop. Some of the army officers suggested that the army mules should be loaned or given to the negroes to enable them to go to work and support themselves.

These attempts in 1865 and 1866 to find homes and employment on the "confiscated" land were frustrated by the gradual restoration of these lands to their former owners. While they were in possession of these lands the freedmen were not very successful. The uncertainty of their tenure conduced to the failure of these settlements. The officers of the government divided some of these confiscated lands, of which the titles had been perfected by judical process, into small lots of teu acres or less and sold them to freedmen on easy terms. But all these efforts to

3See the following references in regard to the plans of the army offcers to put the negroes to work and to settle them on the abandoned lands: Gen. Howard's report, p. 644, Messages and Documents of the U. S. Government, 1866-67; Gen. Halleck thought the 100,000 negroes under the direction of the Federal Government in Virginia should be given the use of condemned animals to raise crops, p. 1138, serial 97, Official Records of War of Rebellion; Gen. MuKibbin's report, p. 1159, serial 97, Offlcial Records of War of Rebellion; Gen. Hartsuff's Order', pp. 932-983. 1185, Official Records of War of Rebellion, serial 97; Messages and Documents of U. S. Government, 1868-69, pp. 508-509; Messages and Documents of U. S. Government, 1866-67, p. 668; Gen. Halleck, 1296, 1005, serial 97, Official Records of War of Rebellion; Charlottesville Chronicle, Feb. 28, 1867.

4P. 658, Globe, 1865-66. The number was probably not so great. 
secure homes for the negroes reached only a very small number of the hundreds of thousands of restless and unemployed colored people of the State.

There was a more or less well defined hope in the bosom of all the negroes that there were other and better things to come to them. About Christmas each year the report was spread abroad amongst the credulous colored people that they were soon to be given the farms of their former masters. ${ }^{5}$ This expectation was strong during the autumn and early winter of 1865 . Very naturally these expectant landlords did not wish to enter into any permanent contract as laborers.

The great body of the negroes in Virginia was engaged in the cultivation of tobacco. This crop requires regular and careful attention from the time it is planted until it is ready for the warehouse, a period of from ten to twelve

'P. 79, App. Globe, 1865-66.

"Reports having been received at these headquarters that the freedmen in some parts of the State refuse to enter into just and reasonable contracts for labor, on account of the belief that the United States gov" ernment will distribute lands among them, superintendents and agents of this bureau will take the earliest opportunity to explain to the freedmen that no lands will be given them by the government; that the government bas but a very small quantity of land in the State-only enough to provide homes for a few families, and that this can only be secured by purchase or lease. They will also explain to them the advantages of at once entering into contracts for labor for the coming year, and that the system of contracts is in no way connected with slavery, but is the system adopted by free laborers every where. It is believed that the renting of small tracts of land by the farmer to his laborers would be mutually beneficial. The laborer's interest in his crops and improvements would attach him to the plantation, counteract any temptation to break his contract, and by furuising employment for the more dependent members of his family, increase their contentment and their comforts.

"The plan of renting lands on shares to the freedmen has been successfully tried in some parts of the State, and is believed to be worthy of a more extended trial. Superintendents will counsel with and assist both parties in making either of the above arrangements." Instructions to agents in Virginia, issued Sept. 19, 1865, by Col. O. Brown, Assistant Commissioner of Freedmen's Bureau, printed in Documents Relating to Reconstruction, edited by W. L. Fleming, University West Virginia. 
months. Through spring, summer, and autumn it must have daily care. Probably no other great agricultural product in the United States requires such assiduous care for so long a period. No planter therefore could venture to plant a tobacco crop unless there was a stroug probability that his laborers would remain with him through the year. The labor supply was very unsatisfactory during the season of 1865 , and promised to be so for 1866, owing to the disinclination of the negroes to form long contracts or to respect them when formed. The issue of rations by the Freedmen's Bureau to the negroes made it possible for many of them to live in idleness and was a standing invitation to them to flock to various agencies and to find support without work, while waiting for the good the future was to bring.

With these difficulties confronting them the people set to work to develop a contract system of labor that would be fair to all. The attempt on the part of certain counties to fix a general rate of wages was a failure both from its inherent weakness and from the opposition of the Federal authorities. During the summer of 1865 various plans were proposed and to some extent put into operation. One of these plans was to furnish the negroes cabins, some land for a garden and for a small crop, with the understanding that the negroes were to work at a stipulated wage for the owner of the land when their services were needed. This system proved fairly satifactory to both the whites and the blacks. There continued, however, to be considerable complaint on the part of the whites that the labor was not reliable and that the negroes did not respect the obligation of their contracts. ${ }^{\circ}$

The number of negroes cultivating rented farms on their own account was not large during the years 1865-67.

6For form of contract with freedmen, see Whig, Dec. 25, 1865. For violation of contract, Whig, Nov. 3, 1866. Complaints of violated contracts is common in the newspapers of that time. 
For this there were several causes. The chief of these was that the negroes had not sufficient capital to furnish themselves with food while making the crop, even if the land owner furnished the land, the tools and the work stock. In most cases it was necessary for the landlord not only to furuish land, stock and tools but also to advance a suffcient sum in cash or credit to buy food for the negro and his family while making the crop. This involved a considerable outlay of money as well as considerable risk as the negroes did not prove highly successful farmers and were usually dissatisfied with the settlement of the account at the end of the year. Another explanation of the comparatively small number of renters is that the wbites felt that negro labor without the direction and guidance of white men would be a failure. ${ }^{7}$ It has already been mentioned that in one county of the State it was resolved not to rent land to negroes. ${ }^{8}$ Such a feeling, however, was never very general, and where it did exist it arose chiefly from the considerations just mentioned and not from any desire to oppress the negroes. There was no effort by law or general public opinion to prevent the freedmen from renting or owning land, though some few people thought it best not to rent them land.

Free negroes were allowed to own land before the war. dt the close of the war, in 1865, a considerable number of negroes in Virginia had bought real estate. ${ }^{9}$ They were very anxious to own land, since they thought that ownership of the soil was an indisputable mark of freedom. The number buying land in the three years immediately follow-

7For reasons why farmers prefer to hire negroes rather than rent them land, see Bruce, Plantation Negro as a Freeman, p. 212 et seq.

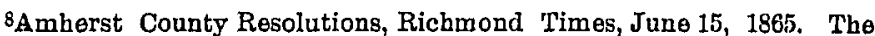
Enquirer (editorial) suggests that the freedmen might become fixtures on the plantations. This is suggested as a solution of the rexed labor question.

${ }^{9}$ Col. O. Brown's Report, Lynchburg Virginian, Jan. 2, 1866. 
ing the war was many times larger than for any three years since 1868. It does not appear that any negro experienced any difficulty in buying real estate either in the country or in the city if he had sufficient means to do so.

Neither the whites nor the negroes found it entirely satisfactory for the negroes to attempt to rent land and farm on their own account. By the close of 1866 the prevailing opinion amongst the farmers of the State was inclined to favor the wage system instead of renting the land to the freedmen. Representative planters declared the results of renting was anything but satisfactory. "The stock loaned was greatly depreciated in value and not enough was made to remunerate the land owner for advances. The negroes as tenants are worthless." 0

A few planters took a little more hopeful view of their colored tenants. By this time the negroes as a race had demonstrated their incapacity for independent enterprise and the direction of their own labor; yet many of them who were especially endowed by nature or had enjoyed superior advantages in slavery were successful and respected men of business.

A wage system was being developed during the years 1865 and 1866. It is diffeult to determine what was the average rate of wages actually paid freedmen in the summer and fall of 1865 . The conditions prevailing in different counties were unlike. In some counties the supply of labor was so abundant and the demand for it so small that the negroes could be hired for their board and quarters. Such was the case in Orange county. In other counties where the demand was active and the number of laborers comparatively small, negro men were eagerly paid twelve dollars per month, the supply not being equal to the demand at that price. This was the case in the Valley

OSee letter of Mayo Cabell in Lynchburg Virginian, Jan. 16, 1867; Gen. Howard's Report, p. 665, Messages and Documents of the U. S. Government, 1867-68. 
counties. In addition to this money payment they received fourteen pounds of bacon, "bone not counted," and one bushel of meal per month, which was supposed to be sufficient to feed a laboring man. In many cases the wages were much lower than ten dollars per month. The wages pail for unskilled agricultural labor did not often exceed this amount. The officers of the Freedmen's Bureau seem to have regarded these wages as high as the agricultural condition justified.

The wage paid in 1866 was higher than that of 1865 . The demand for labor was greater, and the number of laborers was apparently smaller than in the year before. The agents of the Freedmen's Bureau collected statistics in 1866 that showed a marked diminution of the number of negroes in Virginia. One of the Richmond papers deplored the fact that better wages wero drawing off the colored laborers to the Southern states or to the North while few whites were coming in to take their places. ${ }^{2}$ Probably the emigration of the negroes in 1866 was not nearly so large as it was estimated, but the alarm caused by a possible scarcity of laborers and an increased labor demand arising from reviving industry caused an advance in wages.

Gen. Howard declared that the low wages prevailing in Virginia were the effect of supply and demand; yet be thinks that the whites were in many instances unfair to the negroes. ${ }^{2}$ The Freedmen's Bureau officers and the military officers repeatedly declared that business was prostrated, that capital had vanished, and that labor could be employed only at very low wages. The wage paid in 1866 was not much, if any, less than the wage of 1867 . For the year 1867 the rep.rt of the Department of Agriculture gives a table showing the wages in Virginia in 1860 and in 1867. The average annual wage for a negro man in 1860

1P. 765, American Annual Cyclopredia, 1866.

2P. 671, Messages and Documents of the U. S. Government, 1866-67; p. 79, App. Globe, 1865-66. 
was $\$ 105$; in $1867, \$ 102$; for a woman in $1860, \$ 46$; in 1867 , $\$ 43$; for a youth in $1860, \$ 39$; in $1867, \$ 46$. In the preceding table of wages per annum, rations and clothing are included with the money of 1860 , rations without clothing in 1867. The tlothing comprised tw suits of summer clothes, two pairs of shoes or one pair of boots, and sometimes a pair of blankets. ${ }^{3}$

A comparison of the wages of 1860 with those of 1867 shows that the labor of a free negro in 1867 was not as well paid as was the labor of a slave in 1860. The service of a slave was undoubtedly worth more than that of an excited and restless freedman, who was, according to all testimony, much less efficient as a freedman than as a slave. It is proper to mention that wages in Virginia were lower than in any other of the seceding states except South Carolina. The feverish excitement in cotton planting in 1866 was responsible for the much higher rate of wages prevailing in most of the cotton states.

The wages paid freedmen in Virginia during this period were severely criticized by the friends of the negroes outside of the State. The Secretary of the Treasury, Mr. Fessenden, had, July 29, 1864, fixed a scale of wages as follows: From eighteen to forty years of age, males, $\$ 25.00$ per month; females, $\$ 18.00$. From fourteen to eighteen and from forty to fifty-five, males, $\$ 20.00$; females, $\$ 14.00$. Over fifty.five and from twelve to fourteen, males, $\$ 15.00$ per month; females, $\$ 10.00$. The wages were not for skilled labor alone, but for all able-bodied colored persons. ${ }^{4}$

The proposal of such a scale of wages disinclined the negroes to take work at the wages current in the State. A feeling grew amongst them that they were entitled to three or four times as much as they were getting for their work. In the "Hunnicutt Convention," assembled at Richmond in

3P. 416, Annual Report of the Department of Agriculture, 1867.

4P. 388, American Annual Cyclopædia, 1864. 
April, 1867, there were about two hundred and fifty delegates, of whom about fifty were whites. In this convention there was much talk of "confiscation" and it was declared that wages were entirely too low. The speeches in this convention show that it was thought that about forty dollars per month was the right figure for ordinary farm labor. ${ }^{5}$

The different attempts to settle the labor question had in the spring of 1867 proved only partially successful. The wage system was winning its way. The negroes were dissatisfied with the current rate of wages and the terms of employment. Their friends outside of the State and their "scalawag" leaders in the State were encouraging them to demand higher wages than have ever been paid to unskilled farm labor, white or black, in the history of Virginia.

\section{CHAPTER VI.}

\section{VAGRANOY AND VAGRaNOX LaWs.}

The efforts to induce the negroes to take up the forms of labor for which there was a demand and for which they had been trained were not entirely successful. They either declined to enter into contracts for labor or ignored them when formed. Many pilfered from the kitchens of the white employers of their friends or lived on the rations drawn from the Federal Government. As late as September, 1865, the Bureau issued to freedmen in Virginia in one month 275,887 rations. In December, $1865,12,058$ negroes were receiving daily rations; about 15,000 were

5Charlottesville Chronicle, April 20, 1867. 
daily fed through the winter. ${ }^{6}$ They sometimes adopted bolder tactics, gathered into crowds in remote parts of the counties, killed the hogs, sheep and cattle of the white farmers and plundered their orchards and fields. In Mecklenburg County, in August, 1565, "the negroes congregated at one or two points, killed the poultry, sheep and hogs and devastated the cornfields and melon patches of the farmers." The most common theme of the editorials of the State press during the summer and fall of 1865 was the idleness and vagrancy of the freedmen.

How to deal with the vagrancy and petty thieving of the negroes was one of the most serious questions of that time. The Richmond Times, June 21, 1865, says: "If severe penal legislation shall become necessary to prevent the free negro from becoming a vagabond and idle thief, the Legislature will provide the remedy." Many newspaper correspondents were of the opinion that some system of "force" was necessary to break up vagrancy amongst the freedmen. The Lynchburg Virginian, June 12, 1865, said: "Large numbers have deserted the plantations and seek to congregate in the cities, so that the most stringent police regulations may be necessary to keep them from overburdening the towns and depleting the agricultural regions of labor. The military authorities seem to be alive to this fact and are taking measures to correct the evil. But the civil authorities also should be fully empowered to protect the community from this new imposition. The magistrates and municipal officers everywhere should be permitted to bold a rod in terrorem over these wandering, idle creatures. Nothing short of the most efficient police system will prevent strolling, vagrancy, theft, and the utter destruction of or serious injury to our industrial sys-

6P. 79. App. Globe, 1865 66. Messages and Documents of the U. S. Government, 1866-67, p 651, 672. P. 378, A merican Annual Cyclopædia, 1865.

'Ricbmond Times, Aug. 16, 1865. 
tem." Nov. 4, 1865, the same paper said: "Therefore to prevent the influx of this population to our towns and cities the Legislature will be obliged to pass laws of sweeping character. A system of registration must be adopted and the vagrant laws must be revived and rigidly enforced. Apprenticeship, to prevent young negroes from growing up in idleness and vagrancy, should be a settled policy, to be regulated upon some system of justice and fair dealing between both parties. The penalty of vagrancy should be virtual servitude and apprenticeship to labor of some kind tor a limited period, for only by some such means as these will we be able to make this character of labor available."

In September, 1865, the Lyuchburg Virginian, in an editorial, says: "Already measures are being taken to compel the newly freed man to labor, and we hope, little confidence as we have in the inclination of the negro to labor without the application of some kind of force, that a system will be adopted to supply the lack of labor that is now experienced."

In September, 1865, the agent of the American Bible Society, in compliance with Governor Pierpont's request, after visiting Petersburg, Farmville, Lyuchburg, Bedford City and the country surrounding these cities, says, in regard to the negro: "The number of able-bodied men is small; in respect to labor a goodly number of the ablebodied are industrious and doing well for themselves and families; numbers must perish unless aided by charitysome estimates make one-half, some one-third, some a very few as dependent on charity; some negroes everywhere feel that they have no responsibility in caring for their wives or children or their own personal wants and live to some extent on what does not belong to them."

8Daily Dispatch, Jan, 4, 1865, had said that the condition of the freo negro will be more pitiable than that of the slave and that a new slavery will arise.

These quotations are talien from the brief informal report left in the Governor's offlce. See Lynchburg Virginian, Sept. 9, 1865. 
In denial of all these charges Senator Sumner read in the United States Senate the following letter "from a government officer of Virginia:" "With regard to the freedmen there is every disposition on their part to make them odious. They constantly talk of insurrection, insubordination, thieving, idleness and every species of crime and vice, all of which I assure is entirely filse, for all cases of thieving certainly, I am sorry to say, are done by whites."

It is surprising to read that "a goverument officer of Virginia" ever reported that "all cases of thieving are done by whites;" yet so excited and credulous were the partisans of the negro that such sweeping statements were solemuly read in the United States Senate by such senators as Sumner, Wilson, and others of almost equal intelligence.

On the other hand the wildest reports of the licentiousness, vagaboudage and starvation of the freedmen were believed. Senator Doolittle, in a speech at New Haven, Connecticut, in 1865, declared that at least one million negroes had perished from 1860 to 1865 ; be did not doubt that the census for 1870 would show that at least two-fifths of the negroes had perished from disease, starvation and vice. $^{1}$ A writer in Blackwood's Magazine declared in 1866 that almost one-half of the negroes in the United States had perished in the last six years. ${ }^{2}$ In some places in the South the mortality was thirty per cent. of the sick. ${ }^{3}$ Some thought the negroes as freemen would disappear as the Indians and buffuloes were disappearing. Many were alarmed at the drunkenness prevailing amongst all classes and sexes of the colored people."

OP. 93, Globe, 1865-66.

IP. 810, American Annual Cyclopædia, 1865.

2Blackwood's Magaxine, May, 1866, p. 532.

3P. 376, American Annual Cyclopæedia, 1865.

${ }^{4}$ Richmond Times, July 3, 1865.

Mr. Dawson's speech, Congressional Globe, 1865-18b6, p. 542.

For vagrancy and mortality of the negroes, see Enquirer, Nov. 15, 1865, March 22, Sept. 18, 1866, April 18, 1867; Whig, Dec. 1, 1865, Uct. 2, Nov. 5, 1866; Republic, Aug. 10, 1865. 
It is now well known that the negro did not suffer so severely from idleness, dissipation and disease as was believed to be the case at that time; nevertheless be suffered much.

The army officers were alarmed at the prevalence of vagrancy during the year 1865 . In an order of June 1 , 1865, General Gregg, stationed at Lynchburg, says: "No freedman can be allowed to live in idleness when he can obtain any description of work. Should he refuse to work he will be treated as a vagaboud." June 2,1865 , he issued the following order: "Able-bodied men will be prevented, as far as it is possible to do so, from deserting the women, childreu and aged persous; and where there is no good cause shown why they left, they will be sent back." Gen. Wright, in an oraier issued at Danville, speaks of the danger "from vagrant negroes." Gen. Duval, at Staunton, June 12, 1865, gave notice "that all negroes now roaming the country will be made at once to break up their idle pursuits and seek employment."

In his report for 1865 Gen. O. O. Howard, Commissioner of the Freedmin's Burean, says there was much unnecessary idleness amongst the negroes in Virginia. He thinks this vagabondage arises in part from the meagre wages paid the freedmen. Col. O. Brown, Assistant Commissioner of the Freedmen's Bureau for Virginia, in an order of November 10, 1865, suys in regard to the vagrancy of the negro: "Where employment is offered on terms that will provide for the comfortable subsistence of the laborers, removing them from the vices of idleness and from dependence on charity, they should be treated as vagrants if they do not accept it, and the rules of the Bureau applicable to such cases should be rigidly enforced; while the freedmen must and will be protected in their rights, they must be required to meet these first and most essential conditions of a state of freedom, a visible means of support and fidelity to contract." In his report of Jan. 2, 1866, 
Col. Brown said: "In the neighborhood of Norfolk, Fortress Monroe and Yorktown about seventy thousand negroes had been collected during the war." * * * * "In other districts thousands of freedmen were roaming about, without settled employment and without homes. In localities least disturbed by the pressure or conflict of armies and where the average amount of land was under cultivation the crops were suffering from want of proper attention." 5 Col. Brown thought that the vagrancy prevailing during the year 1865 was owing to an excessive supply of laborers and inability of the whites to employ and co-operate with free labor, since they had been accustomed to deal only with slaves.

In August, 18t5, the Freedman's Journal, of Alexandria, declared there would be intense suffering amongst the negroes in large numbers who were not laying up anything for the coming winter, but were either idle and unemployed, or dissipating their earnings for drink or trifles. ${ }^{6}$

The actual vagrancy was not as great as it appeared to many people at that time. Before the war nearly all the negroes in Virginia had been slaves and had consequently been kept closely employed on their owners' plantations. People were unaccustomed to the sight of lounging, idle negroes, and were therefore the more alarmed at the idleness and vagrancy of the late slaves. It is the opinion of some citizens who lived through that period that the negroes were not less industrious than at present, yet the people were alarmed at the unwonted idleness of the freedmen and demanded remedial legislation of the General Assembly.

The Legislature met early in Decernber, 1865, and

Lynchburg Virginian, Jan. 2, 1866.

6Lynchburg Virginian, A ugust 25, 1866. 
passed, on Junuary 15, 1866, the following preamble and act $:^{7}$

"Whereas it is represented to the General Assembly, That there bath lately been a great increase of idle and disurderly persons in some parts of this Commonwealth, and, unless some stringent laws are passed to restrain and prevent such vagrancy and idleness, the State will be overrun with dissolute and abandoned characters to the great detriment of the public weal: For remedy whereof,

"1. Be it enacted by the General Assembly, That the overseers of the poor, or other officers baving charge of the poor, or the special county police, or the police of any corporation, or any one or more of such persons, shall be and are hereby empowered and required upon discovering any vagrant or vagrants within their respective counties or corporations, to make information thereof to any justice of the peace of their county or corporation, and to require a warrant for apprehending such vagrant or vagrants, to be brought before him or some other justice; and if, upon due examination, it shall appear that the person or persons are within the true description of a vagrant, as hereinafter mentioned, such justice shall, by warrant under his hand, order such vagrant or vagrants to be employed in labor for any term not exceeding three months, and by any constable of such county or corporation, be hired out for the best wages that can be procured; to be applied, except as hereafter provided, for the use of the vagrant or bis family, as ordered by the justice. And if any such vagrant or vagrants shall, during such time of service, without sufficient canse, run away from the person so employing him or them, he or they shall be apprehended, on the warrant of a justice, and returned to the custody of such hirer, who shall have, free of any further hire, the services of said vagrant for one month in addition to the original term of hiring; and said employer shall then have the power, if

7Acts 1865-66, pp. 91-93. 
authorized by the justice, to work said vagrant, confined with ball and chain; or should said hirer decline to receive again said vagrant, theu said vagrant shall be taken by the officer upon the order of a justice, to the poor or work house, if there be any in said county or corporation, and be delivered to the overseer or superintendent, who shall work said vagrant for the benefit of said county or corporation; or, if authorized by the justice, to work him, confined with ball and chain, for the period for which he would have had to serve his late employer, had he consented to receive him again; or should there be, when said runaway vagrant is apprehended, any public work going on in said county or corporation, then said vagrant, upon the order of a justice, shall be delivered over by said officer to the superintendent of such public work, who shall, for the like last mentioned period, work said vagrant on said public works, confined with ball and chain, if so authorized by the justice. But if there be no poor or work house in said county or corporation, and no public work then in progress therein, then, in that event, said justice may cause said vagrant to be delivered to any person who will take charge of him. Said person to have his services free of charge, except maintenance, for a like last mentioned period, and said person so receiving said vagrant is hereby empowered, if authorized by the justice, to work said vagrant confined with ball and chain; or should no such person be found, then said vagrant is to be committed to the county jail, there to be confined for the like period, and fed on bread and water. But the persons described as the fifth class of vagrants, in the second section of this act, may be arrested without warrant by the special county or corporation police, and when so arrested shall be taken before a justice, who shall proceed to dispose of them in the mode prescribed in this section, or may at once direct them to be committed to prison for a period not exceeding three months, to be kept in close confinement and fed on bread and water. 
“2. The following described persons shall be liable to the perralties in posed by law upon vagrants:

"First-All persons who shall unlawfully return into any county or corporation whence they have been legally removed.

"Second-All persons who, not having wherewith to maintain themselves and their families, live idly and without employment, and refuse to work for the usual and common wages given to other laborers in the like work in the place where they then are.

"Third-All persous who shall refuse to perform the work which shall be allotted to them by the overseers of the poor as aforesaid.

"Fourth-All persous going about from door to door, or placing themselves in streets, highways or other roads, to beg alms, and all persous wandering abroad and begging, unless disabled or incapable of labor.

"Fifth-All persons who shall come from any place without this commonwealth to any place within it, and shall be found loitering and residing therein, and shall follow no labor, trade, occupation, or business, and have no visible means of subsistence, and can give no reasonable account of themselves or their business in such place.

"3. All costs and expenses incurred shall be paid out of the hire of such vagrant, if sufficient, and if not sufficient, the deficiency shall be paid by the county or corporation."

The langnage of this act applies alike to all persons, both white and black, but it was enacted primarily to sup. press vagrancy among the negroes.

This statute was annulled by Maj. Gen. Terry, then in command in Virginia, in an order issued only nine days after its passage. In this order Gen. Terry sums up the provisions of the act and declares: "The ultimate effect of the statute will be to reduce the freedmen to a condition of servitude worse than that from which they have been 
emancipated, a condition which will be slavery in all but its name." In conclusion of his review he says : "It is therefore ordered that no magistrate, civil officer, or other person shall, in any way or manner, apply or attempt to apply, the provisions of said statute to any colored person in this department." 8

Carl Schurz had said in his report to President Johnson: "Although the freedman is no longer considered the property of the individual master he is considered the slave of society, and all independent state legislation will share the tendency to make him such." It was declared that the vagrant act of January 15, 1866, was only the first step toward enslaving all negroes to the community, which it was alleged had already practically been done in some of the Gulf States. ${ }^{0}$

This statute was not in force long enough to be tested in its practical workings. It was liable to grave abuses; yet it cannot be said, in view of all the facts narrated on the preceding pages, that it was enacted to re-enslave the negroes, either to an individual or to society. This was the only act touching the negroes that was annulled by the military authorities. With the exception of the Contract Law, the Vagrant Act was the only positive enactment of the Legislature that was seriously criticised by the negroes or their friends.

8Pp. 908, 1305, Globe, 1865-66.

${ }^{9}$ Congressional Globe, 1865-66, p. 1305.

OSee the Congressional debates on the Freedmen's Bureau Bill, Civil Rights Bill and the Reconstruction Acts, Congressional Globe, 1865-67. For comparison of the "Black Laws" passed by the Southern Legislatures in 1865-66, with similar laws in the Northern states, see Herbert, Solid South. For full account of these laws, sei Burgess, Reconstruction, and Garner, Reconstruction in Mississippi. For partisan account, se日 Blaine, Twenty Years in Congress, and McCall, Thaddeus Stevens. 


\section{CHAPTER VII.}

CONTRAOT LAWR.

During the year 1865 almost all the contracts between white and colored men for labor were verbal agreements. In many cases they were indefinite in their terms and led to much misunderstanding between the employer and the employee. The negroes, after the lapse of a few months, were surprised to find how much they had received on their wage account and how small an amount was due them. They therefore became discontented, abandoned their work and made complaint of their wrongs before the Federal authorities, alleging that they were denied the wages promised them or were wronged in the payment of the same. Since the contracts were verbal, it was impossible for the courts to determine who was in the wrong.

To obviate this source of dissatisfaction and litigation, the Legislature, February 20, 1866, enacted: "That no contract between a white and a colored person for the labor or service of the latter for a longer period than two months shall be binding on such colored person unless the contract be in writing, signed by such white person, or his agent, and by such colored person, and duly acknowledged before a justice or notary public or clerk of the county or corporation court, or overseer of the poor, or two or more credible witnesses in the county or corporation in which the white person resides or in which the labor or service is to be performed. And it shall be the duty of the justice, notary, clerk, or overseer of the poor, or the witnesses to read and explain the contract to the colored person before taking his acknowledgment thereof, and to state that this has been done in the certificate of the acknowledgment of the contract." 00 In this section of the statute there is no

${ }^{\infty}$ Acts 1865-66, p. 83 . 
discrimination against the freedman, since he can enforce his contracts whether verbal or written, while the white man can enforce his contract with a negro only when it is written and properly acknowledged.

In the account of the evolution of a wage system frequent references were made to the uncertaiuty and unreliability of the colored labor of the State. It was shown that the planting of a tobacco crop, the leading staple in the section of the State occupied chiefly by negroes, was a great risk on account of the trausient and uncertain character of labor. Since the restraints of slavery had been removed from them the negroes seemed to have the idea that they as freemen were bound by no contract or promise, if interest or fancy invited them to violate it. The offer of a slight increase for a day or two in the daily wage would induce the laborers to desert, at the most critical time of planting or harvesting, the planters in whose service they had been engaged at the less critical season of the year under contract to remain until the crop was harvested or the work finished. Frequently no inducement in the form of better pay was necessary to cause them to drop their work and wander away. The advent of a circus or the announcement of a revival meeting meant a more or less protracted holiday for the negroes, regardless of their contracts or the urgency of the work they had agreed to perform.

The Richmond Times, in an editorial of June 10, 1865, says: "The contract, however, does not weigh a feather with the negro. He deserts his employer without a moment's warning, and does not deign to assign a reason for his conduct. He leaves the plow in the unfinished furrow, the dinner half cooked, the half washed linen in the suds, and the patient whom he has contracted to nurse in the midst of the fierce delirium of fever. He laughs at the obligation of his contract, and does not care a tarthing for the injury which his conduct inflicts upon his employer. Is there no remedy for this? Until laws regulating con- 
tracts between our citizens and the negro are enacted, we hope the military authorities will see that all parties are protected and forced to observe their contracts."

During the year 1865 negro labor remained very fickle. It was urged by county meetings of the farmers that the Legislature should at an early date do something to regulate and protect contracts between white men and negroes for labor. Otherwise it was declared that no one could venture to plant extensively or to undertake any great industrial enterprise. ${ }^{1}$

When the Legislature convened in December, 1865, it took up the contract labor question. We have seen that by the first section of the act of February 20, 1866, it was provided that no contract between a white and a colored man for labor for two months or longer was enforceable against a negro unless it was in writing. By the second section of this act penalties were provided for enticing away or employing a negro under contract in writing according to the statute. ${ }^{2}$ The second section reads as follows: "If any person shall entice away, from the service of another, any laborer employed by him under a contract, as provided by this act, or shall knowingly employ a laborer bound to service to another under such contract, he shall forfeit to the party aggrieved not less than ten nor more than twenty dollars for every such offense; to be recovered by warrant before any justice of the pence."

This section provided no direct penalty for the violation of his contract by the negro; yet the indirect consequences to him were very severe. If a negro did not seek and find employment, the statutes of 1866 regarded him as a vagrant and provided for his arrest and forced labor. ${ }^{3}$

${ }^{1}$ For facts in regard to uncertainty and unreliabilicy of negro labor in 1885 and 1886, see the preceding chapter on the evolution of a wage system.

${ }^{2}$ Acts 1865-66, p. 83.

Acts 1865-66, pp. 91-83. 
Few farmers, as dependent on hired help for long seasons as were the tobacco planters in the eastern section of the State, would employ negroes as agricultural laborers for shorter periods than two months; it was therefore necessary for the great body of negro laborers to enter into long contracts for labor or remain unemployed. If they remained unemployed, they were subject to the penalties for vagrancy; if they entered into contracts for labor for two months or longer, they were practically forced to remain with their employer, since it was unlawful for any other planter to employ them while under contract.

Within two weeks after the passage of this act regulating and protecting contracts between white and colored persons, the Legislature, in the fourth section of an act entitled," "An Act to encourage Immigration and protect Immigrant Labor" enacted: "That any immigrant, bound by contract as aforesaid, who shall, without good and sufficient cause, abandon or leave the service of his or her employer, shall be liable to said employer for double the amount of wages for the unexpired term of service; and any immigrant who shall fail to enter the service of an employer agreeable to contract, shall be liable in like manner and for a like amount; and the claim for all such liabil. ities shall be a lien on all future wages of such immigrant, wherever earned, or from whomsoever due, until the same be repaid: and any person who shall employ any immigrant, or otherwise entice any immigrant from his or her employer, shall be deemed guilty of a misdemeanor, and on conviction thereof, shall be fined in a sum not less than the amount of wages for the unexpired term of the contract, and may be imprisoned, at the discretion of the jury trying the case, for a period not longer than six months."

This act in the first three sections legalized labor contracts between citizens of Virginia and Europeans desiring to emigrate to Virginia, by declaring that all such contracts,

4 Acts 1865-66, pp. 284-285. 
even if made in Europe, were enforceable in Virginia. The fourth section above quoted provided penalties for the violation of such contracts more severe than were inflicted on negroes for violating labor contracts. It was hoped that most of the immigrants would come from England and Scotland. ${ }^{5}$ There was certainly no wish on the part of the people of Virginia to enslave these white Europeans whom they were urging by all possible means to come to the State. ${ }^{6}$ It was felt that the employer of labor had certain rights to the service of the employee under contract for long service that ought to be protected by positive statute.

The act of February 20, 1866, regulating and protecting negro labor contracts, and the act of March 3, 1866, regulating and protecting immigrant labor contracts, were both susceptible of abuse; yet it does not appear that it was the intention of the Legislature to imperil the rights of the freedmen or the immigrants, but to force them to respect their contracts. The uncertain character of colored labor in Virginia at that time rendered some drastic contract labor law necessary. It is difficult to propose any that would be more effective or subject to fewer abuses than the act of Feb. 20, 1866.

\section{CHAPTER VIII.}

\section{The Slate Code Repeated.}

The General Assembly of Virginia, in a sweeping bill Feb. 27, 1866, recognized the new condition of the former slaves and free negroes by repealing the chief features of

${ }^{8}$ Acts 1865.66, p. 235.

6Acts 1885-66, pp. 287-298. 
the old slave code. All "acts and parts of acts relating to slaves and slavery" were expressly repealed.?

Chapter one hundred and seven of the Code of 1860 relating to free negroes was repealed. This chapter contained very minute provisions for the regulation of free negroes, for control of their movements and for their expulsion from the State if they failed to comply with certain legal requirements in regard to registration. All these provisions were deliberately swept away by this act.

Likewise chapter two hundred of the Code of 1860 , which provided punishments for offenses by negroes, was repealed. This chapter defined the penalties for a numerous class of crimes by negroes, such as assaults on white men; delivering to a slave a copy of the register of freedom; plotting or conspiring to rebel or make insurrection; making use of "provoking language or menacing gestures to white men;" furnishing "any pass" to a negro; keeping firearms or other weapons; "engaging in a riot, rout, unlawful assembly or making seditious speeches;" selling, preparing or administering any medicine, except a slave administering medicine by his master's orders, or a free negro to his own family or the family of another person with the consent of that person. Under certain conditions a free negro could be sold into slavery. This whole chapter with its long list of special crimes and punishments for negroes was repealed.

Chapter ninety-eight of the Code of 1860 relating to patrols was repealed. ${ }^{8}$ The repeal of this patrol statate indicates a distinct purpose on the part of the Legislature to deal with the negroes as free men.

The Legislature repealed chapter two hundred and twelve of the Code of 1860 relating to the proceedings against negroes. In this act it was declared that, "All laws in respect to crimes and punishment and in respect to

7 Acts 1865-66, p. 84.

8Acts 1865-66, pp. 84-85. 
criminal proceedings, applicable to white persons shall apply in like manner to colored persons (and to Indians) unless when it is otherwise specially provided."

Sections twenty-five to forty-seven, both inclusive, of chapter one hundred and ninety-two, providing penalties and punishments for persons assisting slaves to escape from their masters and to leave the State, were repealed, since the whole slave system was recognized as destroyed. 8

The Code of 1860 , chapter one hundred and ninety. eight, sections twenty-six to twenty-nine, inclusive, made it unlawful for any free person, by speaking or writing, to maintain that the owners had not the right of property in their slaves; or to encourage the slaves to rebel or to make insurrection or to resist their masters. This chapter also provided that postmasters should exercise the utmost precaution to see that nothing of an inflammatory nature in regard to slavery should pass through the mails. All these provisions were repealed by the Legislature Feb. 27, 1866. By this same act, section thirty of chapter one hundred and ninety-eight of the Code, forbidding free negroes to remain in the State without permits of the county court where the negro was a resident, was repealed.

But section thirty-one of chapter one hundred and ninety-eight of the Code of 1.860 was not repealed. It reads as follows: "Any free person who shall bring a free negro into this State shall be confined in jail not more than six months and fued not exceeding five hundred dollars. This section shall not apply to a person traveling into, or through, the State with a free negro as a servant, nor to a master or skipper of a vessel or steamboat, with a free negro on board, who shall depart therewith; but any such free negro who shall be found away from such vessel or boat, or from the lodging of his employer, except on business or with the written permission of such master or employer, shall be punished with stripes."

8Acts 1865.66, pp. 84-85. 
Section thirty-two of chapter one hundred and ninetyeight of the Code of 1860 declared that: "No free negro shall migrate into this State." "For such voluntary migration on the part of a free negro a penalty of stripes and cost of prosecution was to be inflicted on such free negro from time to time until he should leave the state." This section was not repealed.

It is difficult to determine to what extent these unrepealed provisions were executed in Virginia during the period from April, 1865, to April, 1867. The writer has found no well authenticated instance in which auy free negro or white man was punished for violation of either of these provisions. Besides, it is expressly stated in the act of February 27, 1866, repealing other sections of chapter one hundred and ninety-eight of the Code, that, "All acts and parts of acts imposing on negroes the penalty of stripes where the same penalty is not imposed on white persons," are repealed. ${ }^{9}$ These sections of the Code of 1860 , impairing the movement of free negroess into the State, were allowed to remain on the statute books while the penalty for violation of them was repealed by the part of the act just quoted, since no white persons were subject to stripes for migrating into the State.

By this same act of Feb. 27, 1866, the statute prohibiting harboring negroes, the assembling of negroes for worship when such worship was conducted by a negro, and every assemblage of negroes for the purpose of instruction in reading and writing, or in the night time for any purpose, was repealed. The laws prohibiting white men from meeting with negroes to instruct them, or to participate with them in any assembly, were repealed. At the same time all restraints on the freedom of buying and selling agricultural produce were removed from the negro population. ${ }^{0}$

Acts 1865-66, p. 85.

OActs I865-66, p. 85 . 
A marked advance toward the full recognition of the negro as a freeman was made when the Legislature repealed the statute prohibiting negroes from owning firearms, swords or other weapons or ammunition. ${ }^{1}$ This statute was repealed despite the fact that many people in the State felt that it was unsafe and unwise to allow the negroes to possess arms ${ }^{2}$ in such an unsettled state of affairs as prevailed from 1865 to 1867 , when it was feared that the negroes would reproduce the horrible excesses of the West Indiau freedmen.

\section{CHAPTER IX.}

Outrages on Freedmen, and the Civil Codrts

From 1865 то 1867.

The emancipation of more than one-half million slaves in Virginia at the close of a prolonged war presented many serious problems for solution. Tens of thousands of soldiers familiar with violence were returning to their homes. A laxity, a lawlessness, a proneness to commit crime and indulge in deeds of violence are the unfailing consequences of war, and especially of civil war. This disposition did not exist in Virginia alone but was felt throughout every state in the Union, even in the Northern states farthest re-

${ }^{1}$ Acts 186566 , p. 85.

2Whig, Jan. 4, Jan. 15, Aug. 4, 1866. The Confederacy had taken steps to enroll slaves as soldiers in the Confederate army in the spring of 1865. Examiner, March 18, 1865; Dispatch, March 25, 1865; Schwab, The Confederate Btates of America, page 194. 
moved from the theatre of the war. ${ }^{8}$ The presence of a lately emancipated race, excited by their new-found freedom and insolent toward their former masters, aggravated the otherwise serious problem of restoring law and order in the prostrate State. There were many acts of violence and many personal encounters between whites and blacks, yet the surprising fact is that there were not more. The explanation of this is that the great mass of the whites felt no bitterness toward the negro for the events of the four preceding years. They felt that the colored people had done little or nothing to secure their freedom. They did not hate them or wish to do violence to them, but simply regarded them as an inferior race for whom they felt a kindly contempt. ${ }^{4}$ Very few, if any, were outraged or murdered from any effort or disposition on the part of the whites to undo their emancipation or to deny them the enjoyment of their freedom. ${ }^{5}$ The disputes and frays between the whites and blacks were generally the difficulties that are likely to accompany the intermingling of races radically different.

Senator Cowan of Pennsylvania, after an examination of the charges made by Senator Wilson, said in the United States Senate in regard to the alleged outrages on negroes: "Testified to by nobody either, except agents of the Freedmen's Bureau, and other fellows of an equally interested stripe, who, like the hair worms, only wriggle in muddy water. These fellows, male and female, have found the woes of the negro such an easy and profitable way to fame and consideration that, like the dogs of Lazarus, they live by licking his sores; and to hear and see them we would

3President Johnson's message, December, 1865, on returning House Bill No. 613, p. 3839, Congressional Globe, 1865-66.

4Gen. Terry's opinion, Congressional Globe, 1865-66, p. 1833; Ibid, p. 1156; Julian's speech, Ibid, p. 3210; Blackwood's Magazine, May, 1866, p. 595 .

5Charlottesville Chronicle, Feb. 28, 1867; Lynchburg Virginlan, Jan. 3, 1866, Col. Brown'в Report. 
think the world was exceedingly wicked, wholly on account of the negro, and for no other reason. **** I am inclined, therefore, to think that in the first place these killings, if done at all, are not done by any but common offenders. Everybody knows the tribal antipathy existing between the lower sort of white men and negroes, and no one expects that it will not be the source of frequent brawls and quarrels, especially since the blacks have now no masters either to advise or protect them. And the false and foolish notion of equality which you have lately put into the head of the negro amounts only to a standing invitation to every white man to break that head as soon as it insults him. These tales are too monstrous for belief, have no foundation upon which to rest, and the few cases which give rise to them would no doubt show, as usual, that neither of the parties are wholly innocent or wholly guilty. In nine cases out of ten they would turn out mutual brawls, the consequence of which is often the most fitting punishment for those engaged in them. ${ }^{6}$ One man out of ten thousand is brutal to a negro, and that is paraded here as a type of the whole people of the South, whereas nothing is said of the other nine thousand nine hundred and ninety-nine men who treat the negro well." 7

At present nothing seems clearer than that most of the conflicts had no political significance and were only common brawls and combats, such as are summarily disposed of by a police judge or a justice of the peace; yet this long list of disputes and conflicts was paraded in Congress as a justification of the Freedmen's Bureau and as a proof of the insecurity of the rights of freedmen. ${ }^{8}$ The number of such

6App. Congressional Globe, 1866-67, p. 154.

7 Congressional Globe, $1865-66$, p. 96.

8Gen. Howard's report, p. 671, Messages and Documents, 1866-67; Rev. Rickmond's speech, Charlottesville Chronicle. April 25, 1867. See speeches of Benator Wilson, Representative Julian and other radical leaders, Con. gressional Globe, 1865-67. 
difficulties was small, when it is remembered that there were more than one-half million negroes in the State of Virginia. It was never claimed that freedmen in Virginia experienced any difficulty in securing justice from the State courts in suits involving money or property. ${ }^{9}$ It was, however, asserted that juries were inclined to inflict on negroes the maximum penalties of the law, in cases of theft, burglary or such offenses; that they were too rigorous in their condemnation of comparatively mild offenses; ${ }^{0}$ but it was not charged that the proceases of the courts and the decision of the jurors were not strictly according to the statutory provisions of the Code of 1860, which the Legislature in is session of $1865-66$ had made applicable to whites and blacks alike. ${ }^{1}$

It was declared, moreover, very difficult, if not impossible, to secure a verdict against a white man for assaulting or murdering a black. ${ }^{2}$ The great mass of the whites were not disposed to permit any insolence on the part of the negroes. The deep-seated conviction in the minds of the whites that the negroes were an inferior race and should be subordinate to white men in the community, made the whites less tolerant of any independence and aggressive. ness on their part, and rendered conflicts between the two races more frequent. It was often said: "The negro is all right in his place." Of course this means that he is all

sGen. Schofield's opinion, App. Congressional Globe, 1866-67, p. 95; Ibid, Messages and Documents of U.S. Government, 1866-67, p. 240. Judge Sheffey, in his charge to grand juries, urges that equal and impartial justice shall be given to freedmen. This charge was published by special request of the bar of Amherst and Rockbridge counties, Whig, April 23, 1866. For similar charge by Judge Christian, in Henrico county, and for editorial comment on these cherges, see Whig, April 28, 1866.

0Col. O. Brown's Report, Congressional Globe, 1866-67, p. 1569; Senator Van Winkle's statement, Ibid, p. 1465; Gen. Howard's Report, pp. 663-664, Messages and Documents, 1887-68.

ISenator Van Winkle's speech, Congressional Globe, 1866-67, p. 1465.

2App. Congressional Globe, 1866-67, p. 95. 
wrong out of his place. ${ }^{8}$ Most of the Virginians had, and still have, very definite ideas of what a negru's place is. If a negro attempted to cross this more or less well-defined limit and to use insolent and insulting language to a white man, he was liable to suffer the consequences, and juries were not disposed to impose oi his assailant the maximum penalties of the law. On the other hand the wanton assault of a freedman by a white man was severely condemned by the great mass of the whites. For such offenses white juries and courts manifested no sympathy and punished the aggressor with the full penalties of the statute.

The trial of Dr. Watson for the alleged cold-blooded murder of a negro in the summer of 1866 and his acquittal by a white court of his county was the most famous case in the criminal courts of Virginia during this period. It was said that, on very slight prorocation, he had, after a lapse of nearly twenty-four hours, shot and killed a negro, the coachman of one of his neighbors. In November, 1866, Dr. Watson was tried and acquitted in Rockbridge county. Thereupon Gen. John M. Schofield, the militiry officer in command in Virgivia, ordered him rearrested and tried by a military commission under the congressional act of July 16, 1866. On the assembling of the Commission Court a writ of babeas corpus was sued ont before the Circuit Court of Richmond, to which General Schnfield declined compliance, Dec. 19, 1866. In the meantime the Attorney General of the United States had investigated the case and decided that the Commission Court had no jurisdiction. The President then ordered Dr. Watson discharged.4

Gen. Schofield declared the Watson case "a foir type of a large number of cases in Virgivia." If this case was

sBlackwood's Magazine, May, 1866, p. 595.

1American Annual Cycloperlia, 1866, p. 765; Richmond Dispatch, Jan. 4.1867; Congressional Globe, 1866-67, p. 1565; App. Congressional Globe, 1860-67, p. 95; Whig, Dec. 20, 1866; Enquirer, Dec. 18, 1866; Dispatch, Jan. 4, 1867.

8Gen. Schofeld's statement, App. Congressional GIabe, 1866-67, p. 95. 
such as he represented it, the declaration that it was a "fair type" of many other cases in the State is entirely too strong. Hon. S. McD. Moore, of Lexington, Rockbridge county, Virginia, in a letter read by Senator Doolittle in the United States Sente, Feb. 19, 1867, says: "As good order prevails and the laws are generally as well administered as I have known to be the case for the last fifty years." $\mathrm{He}$ declares that most of the reports in regard to the unjust administration of the laws had arisen from two cases in that section of the State. One of the tro cases was the Watson affair. A few such cases as this is said to have been did much to create the impression in the North that the murder of a negro was in Virginia considered perfectly justifiable if the negro had been insolent or insubordinate.

Many in Congress and in the North believed that the average Virginian entertained a deadly hatred of the negroes whom they were anxious to kill as having no longer the place or value of chattel slaves. Entertaining these opinions, they confidently declared that every murder of a negro by a white man and every failure of a court to punish the white man was confirmation of their opinions and rendered vigorous intervention by the Federal Government the only salvation of the freedmen. In their opinion the Freedmen's Bureau, the Freedmen's Court, the Civil Rights Bill, the Military Commissions, and the Reconstruction dets were necessary to protect the lives of the negroes. The number in the United States actually entertaining these opinions was not large, but they were earnest and aggressive. The politicians and the unscrupulous made use of the sincerity of this class for purposes purely personal or for party advantage.

The number of actual outrages was never large. ${ }^{7}$ The

6Congressional Globe, 1866-67, p. 1567.

'Enquirer editorial, July 24, 1866; Whig, Marcb 23, Nov, 22, Nov. 28, 1866. It was alleged by the negroes and their friends that the whites hed, 
press of the State generally declared that good order prevailed throughout Virginia at that time. The Charlottesville Chronicle, February 2S, 1867, says: "We can speak for Virgiuia, there never was less crime (except thieving on the part of the freedmen) in this State. There have doubtless been negroes killed by white men and white men killed by negroes, but on the whole, a more orderly and law-abiding community does not, in our opinion, exist on this continent, if anywhere." The Richmond Dispatch considered that the administration of justice in Virginia was at that time approximately fair and equal.

The freedmen had learned that their most trivial charges against each other or the whites would receive a ready hearing by the agents of the Freedmen's Bureau, and they did not allow the Bureau agents to eat much idle bread. No report of outrages, however absurd or poorly attested, was neglected. The most trivial brawl was magnified into a riot in which many were wounded and killed. By the time these disturbances had been reported in the radical press and announced in the United States Congress by Senator Wilson, or some equally imaginative member of the House, they absolutely defied recognition even by the parties to the original brawl. The "scalawags," "carpetbaggers" and newspaper correspondents industriously gathered and disseminated the reports of outrages on colored people.

Amongst so large a number of people many brawls and petty disturbances wonld occur in the most peaceful times, and under the most ideal conditions; yet the congressional radicals shut their eyes to these facts and made no allowances for the fact that the State was just emerging from a prolonged war, and was further embarrassed by the

in various places in the South, burned or destroyed negro churches and school bouses. Very few, if any, such buildings were destroyed by the whites in Virginia. The Whig, May 7, 1866, declares that no negro churches had been burned by the whites in Virginia. 
presence of the lately emancipated slaves. Senator Wilson and other radical members of Congress brought forward the long list of suits, brawls and outrages as a justification of ' the various acts passed by Congress for the protection of the negroes. In reply to these charges Senator Davis, in a speech in the Senate, after full examination of the lawless acts reported by the congressional radicals, declared that in his deliberate opinion there was not as much lawlessness and violence in any six of the states lately in rebellion as in the single state of New York. ${ }^{8}$ Other members of Congress who had investigated the matter were almost equally strenuous in their denial of the alleged outrages.

The evidence in support of the truthfulness of these charges is to the highest degree unsatisfactory and unconvincing. They were in many cases entire fabrications without the slightest basis of fact. As a single instance of their utter unreliability, it was reported in the radical papers that several negroes had been shamefully outraged at Lynchburg, Virginia. The details of the affair were given with great minuteness; the name of the Freedmen's Bureau agent at that place, maling the official report of what he had seen and learned by investigation, was given. When these reports finally reached Lynchburg no one there had heard of the outrages or auything like them. The Bureau agent declared that no one having the name of the reporter of these lawless acts had ever been connected with his Bureau in Lynchburg; that no such acts had occurred, and that the very best of order prevailed in his entire sub-district. ${ }^{0}$

This report is a fair sample of hundreds that were published in the radical papers outside of the State.

8Congressional Globe, 1866-67, p. 1466 .

9For evidence of the unreliable character of many of the reported outrages and the effect of such reports on Northern public opinion, see Congressional Globe, 1865-66, pp. 1407-1411; Whig, Nov. 3, 1866.

oLynchburg Virginian, Aug. 10, 1866. 
Most of the writers of these letters giving accounts of the assault and murder of negroes asked to have their names kept secret, declaring that it would imperil their lives to have it known that they had reported these outrages. Their wishes were respected, and they were thus emboldened to flood the Congressional Committee on Reconstruction with such reports as malice or party interest could invent.

General O. O. Howard, the Commissioner of the Freedmen's Bureau, in his annual report for 1866, declared that the number of conflicts between whites and blacks in Virginia constantly grew less, and that the position of the negroes was improving, yet the complaint was made that in some parts of the State the negroes were occasionally outraged and that the offenders usually were not punished by the minor judicial tribunals of the State, if it was charged that the negro had been insubordinate or insolent to a white man. ${ }^{1}$

In his report of November, 1866, General O. O. Howard said in regard to the six counties bordering on the Potomac which were included in the military district of Maryland: "The condition of the freedmen in the portion of Virginia included within this district, as shown by the report of General Stanard for the montbs ending May and June, 1866, and the official records for succeeding months, has been generally satisfactory. No complaints of a serious nature were received." 2

In reference to the condition of affairs in Virginia, in the same report he says: "Some improvement is reported in the feeling of the whites towards the freedmen, and jet the numerous murders and robberies of which this office is notified are evidences of bad feeling or weakness

IGen. Howard's Report, Messages and Documents, 1866-67, p. 671. Gen. Schofleld's opinion, App. Congressional Globe, 1866*67, p. 95.

Messages and Documents, 1866-67, p. 688. 
on the part of the State officials whose duty it is to preserve the peace and to punish crime." 3

The number and character of the outrages on negroes reported to the Freedmen's Bureau were grossly exaggerated. As a rule the Bureau officials did not examine the evidence in support of these charges, but reported and in a large measure acted on ex parte testimony. In times of great pubic excitement the wildest reports gain credence. At that time the air was full of reports of outrages and riots, most of which had not the slightest foundation in fact. Most of the "numerous murders and robberies" to which General Howard refers in his report were of this class.

He made this report abont the time the excitement in regard to the Dr. Watson case was highest, and doubtless had that particular case in mind when speaking of the "bad feeling or weakness" of the courts.

General Terry, the military commander in the Department of Virginia, declared that it would be unsafe to entrust the great body of the freedmen in Virginia or elsewhere in the South to the care of the local authorities or the local legislation.

His chief grounds for this opinion was that the whites hated the negroes on account of their attachment to the "Union," and if the protecting hand of the United States Government were withdrawn would so harrass and embitter their lives that they would rise in bloody insurrection against their oppressors. ${ }^{4}$ It seems never to have been clear to many of the army officer's that the white people of the State did not hold the negroes responsible for the war and its consequences and did not entertain for them any feeling of personal hostility on account of their changed condition.

IIbid, p. 671. See Col. O. Brown's Report, Congressional Globe, 1866-67, p. 1569 .

Testimony of Gen. Terry given before the Reconstruction Committoe, p. 1838, Globe, 1865-66; Enquirer, March 31, 1866. 
Whatever feeling there was that the negro should notenjoy full civil or political privileges did not arise from any hatred of him as a race or as an individual, but from a fixed and firm conviction that he was an inferior race, incapable of the highest duties and privileges of citizenship in a democratic commonwealth.

The whites were always ready to resent any attempt by a negro to force himself into a position of social equality or to assume the political leadership of the community. From these causes arose many of the conflicts between the two races. The number of such conflicts was considerably increased after the passage of the Reconstruction Acts of 1867 and the enfranchisement of the negroes. ${ }^{5}$

Before the passage of the Reconstruction Acts in the spring of 1867, the Ku Klux Klan was unknown in Virginia. No mention is made in the Bureau reports of such an organization until 1868. It was then declared that the operations of these organizations "have been very rare in this State." The word "Ku Klux" as used at that time was a generic term for all lawless secret combinations organized to frighten or maltreat negroes.

Colonel Brown in his report of the operations of the Freedmen's Bureau in Virginia for the month of April, 1868, says: "The secret organization known as the $K u$ Klux Klan have made their appearance in various localities, visiting the houses of colored men, at night in some cases, placing ropes around their necks and threatening to hang them on account of their political opinions. No further violence has been offered. The object of these midnight demonstrations, which have been very rare in this State, appears to be to intimidate and control the freedmen in the exercise of their right of franchise." 6

\footnotetext{
sSee newspapers of the State for increased number of conflicts be-
} tween whites and blacks after the enfranchisement of the freedmen.

6P. 510, Messages and Documents of U. S. Government, 1868-69. 
This is his first reference to such lawless bands. From this report it is seen that the object of these organizations in Virginia was not to plunder or murder negroes but to deter them from exercising "their right of franchise."

The negroes were subjected to some outrages from a very unexpected source. Some of the Federal soldiers in Virginia in 1865 "took considerable liberties with them and their belongings." In some instances they "plundered" them." They "spread the tents and threw up the negroes." In this way many were hurt and some were reported killed. A Federal soldier at Charlottesville relieved Rev. Fairfax Taylor, a prominent colored leader, of his watch. The soldiers stationed in Virginia after the war were frequently engaged in brawls and personal encounters with the freedmen. Some negroes were "tied up" by army officers to force them to tell the truth. ${ }^{8}$ These troubles between negroes and soldiers were of the same kind and originated from the same causes that brought on similar altercations and contests between blacks and native Virginians.

Many agents of the Freedmen's Bureau oppressed and swindled the freedmen. Other persons went about from place to place assuring them that they were soon to be given the land of the former slaveholders. In some instances they went so far as to stake off the farms into sections of about forty acres each. These lands were to be given then as pay for their past services as slaves and for their devotion to the Union. Frequently these impostors pretended to put the credulous negroes in possession of the land, and collected a fee to pay for the title deed which they gave them to establish their ownership. One of the deeds given to an Albemarle county negro read as follows: "As

7Waddell, History of Augusta County, pp. 819, 325; Ibid, 337-838.

8Messages and Documents of U. S. Government, 1867-68, p. 289. 
Moses lifted up the serpent in the wilderness, so have I lifted five dollars out of this nigger's pocket."

The belief that they were to be given the lands of the late Confederates persisted in the minds of the freedmen for several years after the close of the war. The fact that the lands seized by the United States Government, the so-called abandoned lands, were then occupied by the negroes under the direction of the Freedmen's Bureau, led the great mass of them to believe that they, too, would soon secure their share of land. This credulous and expectant attitude of mind rendered them ready victims of the unscrupulous "scalawags" and "carpetbaggers," who did not neglect the opportunity to enrich themselves at the expense of their dupes. Their ingenuity in devising plausible schemes for swindling the negroes was truly admirable. Many of them represented themselves as confidential agents of influential government officials, or as friends and representatives of philanthropic individuals or societies in the North, who were said to be preparing great things for the negroes. After winning the ready confidence of the freedmen they received from them, under various pretexts, considerable sums of money, and created expectations that could never be realized.

Quite a serious riot broke ont in Norfolk in the night of April 16, 1866. The freedmen met to celebrate the passage of the Civil Rights Bill. About twelve o'clock a shot was fired on Nicholson street. A general row followed. An innocent white spectator named Whitehurst was shot dead; Mrs. Whitehurst (a white woman) was mortally wounded; several others were hurt, and one negro was shot in the eye. There was much drinking amongst the colored people that night. One colored woman was arrested on account of her inflammatory and threatening language. Major Stanhope, of the United States army,

9Most of the facts in regard to these impostors were obtained from nogroes who know them from personal experience. See Documents Relating to Reconstruction, (passim), edited by Fleming. 
immediately sent out an armed force and dispersed the mob. In a short time four arrests were made. ${ }^{0}$ In regard to this tumult there were various conflicting reports. ${ }^{1}$

From this review of the "outrages on negroes and the action of the courts" it is seen that the actual number of outrages was small when it is considered that more than one-half million freedmen were turned loose amongst a white population of more than seven hundred thousand, at a time when society was demoralized by the results of war; that the whites did not cherish any hatred toward the negroes on account of the events of the preceding four years; that the combats between whites and blacks did not, in most cases, arise from any attempt to undo or minimize the results of emancipation, but were generally the results of mutual brawls; that some of the attacks on negroes by white men were provoked by insolence or insulting language on the part of the blacks; that in such cases the courts of Virginia sometimes refused to find the white aggressors guilty of any offense; that the courts had little disposition to excuse or acquit a white man who had assaulted or murdered a negro who had not been insolent or insulting and had conducted himself in the manner which most white people thought becoming a free negro; that freedmen in the Virginia courts experienced little or no difficulty in securing justice in money or property matters; that in proceedings against negroes charged with thefts, burglaries, and murders, juries nsually imposed something like the maximum penalties. It has been seen that they were sometimes wronged by their supposed friends, the soldiers, "the scalawags" and "carpetbaggers." From the reports of the officers of the Freedmen's Bureau and the press, it is seen that the condition of the freedmen was constantly improving from 1865 to 1867 ; that lawlessness in the State was rapidly decreasing, and that the decisions of the civil courts were approaching fairness.

OLynchburg Virginian, April 20, 1866.

${ }_{1}^{1}$ According to some reports two negroes were killed. 
CHAPTER X.

Freedren and Crvin Rights in 1865 and 1866.

The Legislature that convened in Richmond in December, 1865 , met under the provisions of the constitution promulgated at Alexandria, in 1864, by the "restured government" of Virginia. The constitution of the State in force before and during the war had fallen with the State government at Richmond.

The Alexandria constitution had abolished slavery by the following provisions: "Slavery and involuntary servitude (except for crime) is hereby abolished and prohibited in the State forever." "The General Assembly shall make no law establishing slavery or recognizing property in human beings." The Legislature of "restored Virgivia" had, however, enacted but few laws in regard to negroes.

At the close of hostilities in Virginia people recognized that the results of the war had effectually freed the slaves; yet there had been no State legislation to define their status. The old "free negro" laws of the Code of 1860 were still on the statute book." The slaves had, so far as State legislative enactments are concerned, succeeded to the status of "free negroes" as defined by the Code of 1860 , but the war had done more than this for them. The white people of the State knew that the Legislature would have

${ }_{2}$ A delegation of negroes from Richmond called on President Johnson in June, 1865, and claimed that their condition as freedmen was worse than it was when they were slaves. They stated that passes were required of them in Richmond; that the old free negro laws still prevailed; that they experienced difficulty in holding their church property; that they could not appeal to the courts for justice and protection, and that they suffered numerous other wrongs. President Johnson told them that matters were in a state of transition and that many things must be endured until they could be remedied. Republic, June 19, 1865. 
to define anew the rights of free colored men, and sooner or later grant to them the whole list of civil rights and some political rights.

Owing to the peculiar situation in Virginia it was difficult to effect an early meeting of a representative law. making body to adjust the laws of the State to the changed conditions. A representative General Assembly of the State convened in December, 1865 , and immediately took up the question of the freedmen.

In a joint resolution the Legislature, February 6, 1866, expressed its opinion on slavery and the future position of the freedmen in the following language: "That involuntary servitude, except for crime, is abolished, and ought not to be re-established; and that the negro race among us should be treated with justice, humanity and good faith; and every means that the wisdom of the Legislature can devise, should be ased to make them useful and intelligent members of society."

"That Virginia will not voluntarily consent to change the adjustment of political power as fixed by the Constitution of the United States; and to constrain her to do so in her present prostrate and helpless condition, with no voice in the councils of the nation, would be an unjustifiable breach of faith."

This resolution expressed about what the white people of the State felt. The statement that Virginia would not voluntarily consent to change the adjustment of political power was intended as a declaration of hostility to the enfranchisement of the freedmen, which the people were unwilling to accept, either in 1866 or in 1867 , when it was thrust upon the State by congressional legislation.

In January and February, 1866, several important bills tonching the freedmen were enacted into laws. About nine months had by that time passed since the close of hostilities in Virginia and the practical emancipation of

3Acts, 1865-66, p. 449. 
every slave in the State. In the meantime, the legal position of the freedmen was very indefinite.

March 3, 1865, Congress had passed a very mild Freedmen's Bureau Bill, which lacked all the drastic features of the Freedmen's Bill of 1866 . The purpose of this bill in 1865 was only to assume charge of all "abandoned lands" and the control of all subjects relating to freedmen. There was a real need of some such agency as this bill provided to advise and protect the freedmen during the summer and fall of 1865 . The opposition to the presence and work of the Bureau agents was not so bitter in 1865 as it was in the years following, when they were invested with much greater power, and the necessity for their interference no longer existed. ${ }^{4}$

By the Code of 1860 free negroes were allowed to testify only in the case of the Commonwealth for or against a negro or an Indian, or in a civil case to which negroes or Indians only were parties. They were not allowed the right of trial by jury, to carry arms, or to be away from their place of abode later than ten o'clock at night. They were also subject to many other minor restraints that were unnecessary and impracticable in the changed state of affairs in the summer and fall of 1865 .

Although there had been no statutory change, the peuple felt that the status of the free negro had in fact been revolutionized. In the Alexandria County Court a negro was put on trial without a jury in September, 1865, and sentenced to two years in the penitentiary. The negro's counsel moved to arrest the judgment on the ground that the negro, being a freeman, had the right of trial by jury. The opposing counsel contended that the free negro proceedings were legal, the Code of Virginia providing that a free negro should be tried for a felony by a court of five justices of the peace and not by a jury. The court com-

${ }^{4}$ Compare Act of March 3, 1865, (p. 141, App. Globe, 1864-65,) with that of July 16, 1866, (pp. 366-367, App. Globe, 1865-66). 
posed of five justices of the peace sustained the negro's counsel in his appeal. ${ }^{5}$

From this decision and similar ones it is seen that, while the letter of the law remained unchanged, the spirit of the times had swept away many of the legal discriminations against free colored men.

In the same county, in October, 1865, a justice of the peace had a negro deprived of a fowling piece, on the ground that the statutes of Virginia did not allow negroes to bear arms. A provost judge revoked this action, declaring negroes had "all the rights of whites and no less."

There was on the part of the whites no serious effort to enforce most of the old "free negro" laws. There were few attempts to disarm freedmen in accordance with the provisions af the Code. General Terry was petitioned by the whites to disarm the negroes in certain sections because they were threatening to make an insurrection against the whites. ${ }^{7}$ On the whole, there was comparatively litile opposition to the negroes' owning and carrying arms, or to their conducting tbemselves as free men, as long as they were not "saucy" or "iusolent" to the whites.

In discussing the social position of the freedmen in October, 1865, the Lynchburg Virginian says: "His social condition is not so much changed after all. The negro is the laborer and menial after all. He now collects his own wages with which to pay his own rent, clothing, taxes and doctor bills. In other respects, his relation to his master has undergone very little alteration."

February 28, 1866, the General Assembly passed the

\footnotetext{
sLynchburg Virginian, September 14, 1865.

6Lyuchburg Virginian, October 14, 1865. Nevertheless license authorizing a negro to perform the marriage ceremony was refused by the Court of Hustings, in Richmond, on the ground that there was no law for granting such license. Enquirer, November 15, 1865.

7 General Terry's testimony before the Reconstruction Committee, p. 1884, Globe 1865-66.
} 
following act in regard to negroes as witnesses:" "That colored persons and Indians shall, if otherwise competent and subject to the rules applicable to other persons, be admitted as witnesses in the following cases:

"1. In all cipil cases and proceedings, at law and in equity, in which a colored person or an Indian is a party, or may be directly benefitted or injured by the result.

"2. In all criminal proceedings, in which a colored person or an Indian is a party, or which arise out of an injury done or attempted or threatened to the person, property or rights of a colored person or Indian, or in which it is alleged in the presentment, information or indictment, or in which the court is of opinion, from other evidence, that there is a probable cause to believe that the offense was committed by a white person, in conjunction or co-operation with a colored person or Indian.

"3. The testimony of colored persons shall, in all cases and proceedings, both at law and in equity, be given ore tenus and not by deposition; and in suits in equity, and in all other cases in which the deposition of the witness would regularly be part of the record, the court shall, if desired by any party, or if deemed proper by itself, certify the facts proved by such witness, or the evidence given by him, as far as is credited by the court, as the one or the other may be proper under the rules of law applicable to the case; and such certificate shall be made part of the record."

Before the war a negro or an Indian was a competent witness only in the case of the Commonwealth for or against a negro or an Indian or in civil cases to which negroes or Indians only were parties. ${ }^{9}$ This new statute of Feb. 28, 1866, declared that they should be heard as witnesses in any and all suits to which any colored person was a party or in which the interest, direct or indi-

8Acts 1865-66, pp. 89-90.

9Code of Virginia, p. 724. 
rect, of a colored person was involved, or in which any crime had been done or attempted to be done or threatened to the person, property, or rights of a colored person.

At the time of the passage of this act almost all the cases involving the interests of colored people, or crimes against their person, property or rights were adjudicated in the Freedmen's Court or in other judicial tribunals of Federal creation. Before these courts there was no distinction of witnesses on account of race and color. These courts from the first recognized that the negroes were entitled to as "full and equal benefit of all laws and proceedings for the security of person and property as is enjoyed by white citizens, and are subject to like punishments, pains and penalties and to none other, any law, statute, ordinance, regulation or custom to the contrary notwithstanding."

It cannot be said that the limitation of negroes as witnesses to cases directly or indirectly concerning the interest or welfare of some colored person was a denial of any "right," since the power to "testify" in cases in which the witness is not a party interested in the outcome of the suit, cannot be claimed as a right; but it is to be regarded either as a privilege conferred by the community on the would-be witness, or as a duty imposed on him for the good of society. Yet whatever may be the abstract philosophy of the matter it was in fact a discrimination against negroes to limit their testimony to particular cases.

While the General Assembly at Richmond was repealing the old slave code and trying to define the rights and privileges of the freedmen, Congress was debating the Civil Rights Bill, which was passed over the President's veto, April 9, 1866. This bill declared "all persons born in the United States and not subject to any foreign power, except Indians not taxed," citizens of the United States; and, in addition to the right to testify in all cases on the same terms as whites, it conferred on the negroes about all the rights enjoyed by white men except the right to sit on 
juries, to vote, and to hold office. It also provided penalties for any attempt, on the part of any individual or any municipal or State officer, to curtail or deny these rights. ${ }^{0}$

The effect of this bill was very far-reaching. It emboldened the negroes to demand various privileges they had not yet enjoyed. As a single instance of this it may be well to mention that, for about one year after the close of the war, it was unsettled whether negroes had the right to ride on public street cars. After the passage of the Civil Rights Bill the negroes toward the last of April, 1866, decided to test their right to ride on the Richmond street cars. This led to some riotous demonstrations, but the president of the road, after an interview with General John M. Schofield, the military commander in Virginia, determined to recognize the privilege. Many of the citizens were dissatisfied with the concession, yet peaceably acquiesced in it. ${ }^{1}$ For some time the cars were divided into two classes, one of which, indicated by a white ball, was for white ladies and gentlemen with ladies, the other for all classes. This arrangement continued until May, $1867 .^{2}$

The Legislature, February 27, 1866, passed an act declaring: "All laws in respect to crimes and punishments, and in respect to criminal proceedings, applicable to white persons, shall apply in like manner to colored persons and to Indians unless it is otherwise specially provided." "3

By this act all special punishments and proceedings peculiar to negroes, except the minor discriminations against negroes previously mentioned in connection with

OPp. 815-316, App. Globe, 1865-66.

1 American Annual Cyclopedia, 1866, p. 759.

2Charlottesville Chronicle, May 4, 186r.

A colored preacher and his wife were ejected from the cars at Rich. mond in September, 1867. Lynchburg Virginian, Sept. 26, 1867.

3Acts $1865 \cdot 66$, p. 84 . 
"the repeal of the slave code," were abolished. Whites and blacks were thenceforth put on an equality before the law in respect to crimes and punishments.

The Federal military authorities in the State soon after the passage of the acts of February 27 and 28, 1866, trausferred to the civil courts full jurisdiction in all cases in nearly all the counties of the State. ${ }^{4}$ In a few places society was so unsettled and the conflicts between whites and blacks so frequent that the Federal authorities did not feel justified in closing the Provost or Freedmen's courts. In the fall of 1866, General Terry reported that in three counties it had been necessary to restore Bureau courts after they had been abolished. ${ }^{5}$ These courts remained in York County until the close of $1867 .^{\circ}$

After the restoration of the full authority of the civil tribunals in all cases, the agents of the Bureau were required by the order of the Assistant Commissioner of the Freedmen's Bureau in Virginia to be present and to aid the colored litigants by their counsel and advice in all trials within their jurisdiction, including criminal trials or preliminary hearings before justices of the peace, to which a colored person was a party. It was the duty of these agents to make an immediate report of "any instance of oppression or injustice against a colored party, whether prosecutor or defendant, and also in case the evidence of a colored person shonld be improperly rejected or neglected." "They were also required to examine and report if in any instance a justice of the peace, attorney for the commonwealth, grand jury, or other authority refused justice to a colored person by improperly neglecting a complaint or declining to receive an oath or sworn information tendered

4P. 671, Messages and Documents of U. S. Government, 1866-67, p. 683; Ibid, p. 65; House Document No. 120, 1st Session 39th Congress.

5P. 671, Messages and Documents of U. B. Government, 1866-67.

BP. 664, Messages and Documents of U. S. Government, 1867-68. 
by such a person whereby a trial or prosecution might be prevented through partiality or prejudice."

After the passage of the act of February 28, 1866, negroes were in some instances denied the right to testify in cases in which they were interested. A flagrant example of such denial was reported of the York County Court at its session held May 19, 1866. The proceedings of this court were reported by the Freedmen's agent, but it does not appear that either the Federal or State authorities took any steps to punish the offenders. ${ }^{7}$

In the Circuit Court of Alexandria Judge Thomas, in 1866, decided in a case in which it was attempted to introduce colored testimony, that such testimony was inadmissible and that congressional action could not make it admissible, since the State had a right to decide who were com. petent to testify and had decided that colored testimony was not admissible in civil suits to which white men alone were parties. This decision of Jurlge Thomas was according to the law of Virginia as laid down in the Act of February 28,1866 , in regard to negroes as witnesses, but it was declared to be an intringement of the Civil Rights Bill. The case was therefore removed to the United States District Court. ${ }^{8}$

A little later five magistrates of the Corporation Court of Norfolk refused to receive the testimony of a negro. A process was issued under the Civil Rights Bill in accord. ance with which the offending officials were arrested and held to bail to appear at the following term of the United States District Court. ${ }^{9}$

It does not appear that there were many attempts in Virginia to infringe the Civil Kights Bill in form, though it was often infringed in spirit, the two cases above men-

TPp. 46-47, House Document No. 120, 1st Session 39th Congress.

8P. 765, American Anpual Cyclopædia, 1866.

9P. 759, American Annual Cyclopædia, 1867. 
tioned being the most prominent instances of its formal infringement.

The Civil Rights Bill and the new Freedmen's Bureau Bill passed July 16, 1866, encouraged the negroes in their demands for equal rights with the whites. They were therefore not content with the Act of February 28, 1866, allowing them to testify in all cases in which a negro was in any way interested.

April 20, 1867, the Legislature of Virginia passed the following act in regard to negroes as witnesses: ${ }^{0}$

"1. Be it enacted by the General Assembly of Virginia, That the act passed Februar.y 28, 1866, entitled an act in relation to the testimony of colored persons; and the twentieth section of chapter one hundred and seventy-six of the Code of 1860 , concerning the competency of witnesses, be and the same are bereby repealed.

"2. Be it further enacted, That hereafter colored persons shall be competent to testify in this State as if they were white."

This act declared colored persons competent to testify "as if they were white." The partisans of the freedmen declared that this concession was not made from an enlarged sense of duty to the negro, but was the result of external pressure in his behalf.

Whatever may have been the motive of the Legislature, this act came too late to be of any practical value. Seven weeks befor: its enactment, Virginia had, by the passage of the Reconstruction Bill of March 2, 1867, been reduced to a military district, and placed under the control of a Major-General of the United States army.

The State authorities had, in the spring of 1867 , conceded to the negroes freedom, religious liberty, the security of property and person, trial by jury, and the right to testify and to hold land. They also enjoyed the rights of

0Acts $1866-67$, p. 880 . 
assembly and petition, of freedom of speech and the press, and of owning and bearing arms. They were therefore in possession of almost all the rights enjoyed by whites, except the privilege of serving on juries, voting, and holding office.

\section{CHAPTER XI.}

\section{ENFranchisement of the Freedmen.}

The constitution formed by the "restored government" of Virginia at Alexandria in April, 1864, limited suffrage to "white male citizens of the commonwealth." The pressure of the events of the war and the political sympathy of the government at Alexandria had not been sufficiently strong to prompt Governor Pierpont and his Constitutional Convention to enfranchise the negro. ${ }^{1}$ It was therefore not to be expected that the great mass of the people of Virginia, who felt they had nothing to gain and much to lose by such a step, would consent to put the ballot in his hands.

It was generally felt that it was necessary to confer on the freedmen all the civil rights and the political rights enjoyed by women and minors; but that was as much as the whites were willing to concede. Meetings were held throughout the State accepting emancipation, but protesting against the enfranchisement of the negroes. ${ }^{2}$ The representative candidates for office were agreed that Virginia

1 For account of the Constitution of Virginia and the Pierpont Legislation at Richmond in June, 1865, see Globe 1885-66, pp. 1833-34.

2Richmond Times, August 22, 1865. 
was a "white man's" government. Mr. Johnson, one of the most prominent candidates for Congress in the Lynchburg district, declared that he "would keep Virginia out of the Union (unrepresented at Washiugton) forty years rather than tolerate negro suffrage." "The General Assembly of "restored Virginia" was in session in Richmond June 19-23, 1865. Speaker Downey, addressing the Legislature just before adjournment, said: "Whatever they may do to other states, thank God, they cannot saddle negro suffrage upon us."

The press of the State almost universally opposed negro suffrage. ${ }^{4}$ The Richmond Times, June 21, 1865, says: "The former masters of the negroes in Virginia have no feeling of unkivdness toward them, and they will give them all the encouragement they deserve, but they will not permit them to exercise the right of suffrage, nor will they treat them as anything but 'free negroes.' They are laborers who are to be paid for their services and protected as are unnaturalized. foreigners, infants and women, but vote they shall not." The Enquirer, January 25, 1866, opposes negro suffrage, "miscegenation, and negro equality," and declares that it does not like a plan by which "the vote of a white man can be killed by that of a negro." March 24th of the same year it opposes negro suffrage under any condition.

The Whig, December 24, 1866, predicts enfranchisement of the vegroes, and urges the whites to make the negroes their friends. A week later it says that the enfranchisement of the blacks will only add to the Southern representation in Congress if the whites are prudent and wise. This newspaper consistently opposed negro suffrage, but urged the whites to keep the negroes from falling under

${ }^{3}$ Lynchburg Virginian, September 14, 1865.

4 Times, June 21, 1865; Enquirer, June 25, 1865, October 15, 1865, October 25, 1866; Whig, January 25, 1866, December 24, 31, 1866; Dispatch, January 8, 1867 . 
the influence of "scalawags" and "carpetbaggers," if they should be enfranchised by congressional act.

In February, 1867, the Lynchburg Republican maintains that ultimately the ballot must be given to respectable and worthy negroes, and suggests that those paying taxes on two hundred and fifty dollars worth of property be enfranchised. By this qualified suffrage, it was said, the State might escape unqualified suffrage, which the Jacobins in Congress were threatening to impose.

The enfranchisement of the negroes began to be discussed shortly after the war. In June, 1865, a Republican organization formed at Alexandria resolved, amongst other things, "that the Constitution of Virginia should be amended so as to confer suffrage upon, and restrict it to, loyal male citizens without regard to color." This was the first time the Republican party committed itself to negro suffrage in Virginia, but unqualified negro suffrage was not yet advocated. A meeting of the radical Union men of Frederick county, at Winchester, June 28, 1865, opposed the entire exclusion of the colored race from the ballot box.

A negro meeting in Petersburg, June 7, 1865, resolved, "That representation and taxation go hand in hand, and it is diametrically opposed to republican institutions to tax us for the support and expense of the government and deny us, at the same time, the right of representation." "

In November, 1865, a convention of colored men met at Alexandria, severely arraigned the whites of the State and the Pierpont government which had been transferred from Alexandria to Richmond in the early summer of 1865 , and asserted their purpose to claim all the rights of white men, including the franchise. ${ }^{7}$

May 17, 1866, the "Unconditional Union Convention"

sRepublic, June 19, 1865.

6Republic, June 10, 1865.

7Lynchburg Virginian, Nov, 12, 1865. 
met at Alexandria. About sixty delegates representing seventeen counties were present. Many of them were selfappointed. John Minor Botts, a prominent and influential old time Whig, presided. After much debate, a resolution favoring qualified suffrage for both races was adopted. Botts opposed negro suffrage, but would have voted for it if he had believed the people of Virginia would sauction it. ${ }^{8}$

In the radical convention held in Philadelphia, September, 1866, Botte vigorously opposed universal manhood suffrage. The other delegates from Virginia favored it. Rev. James W. Hunnicutt, a delegate from Virginia who afterwards achieved notoriety as a leader of the radicals and negroes, favored the enfranchisement of all men except "rebels." The convention adopted a report favoring "manhood suffrage." Thereafter the Republican party was committed to unqualified negro suffrage.

Various motives influenced the advocates of negro enfranchisement. Many of the radicals were sincere in their efforts, believing that the ballot only would protect the late slaves and fit them for the respousibilities of citizenship. Many white agitators were seeking their own advancement through the black voters. Others wished to avenge themselves upon the former ruling class. The negroes themselves came to believe that freedom without the privilege of voting and holding office was a failure.

The hostility to negro suffrage was not perceptibly mitigated during the year 1866. February 16, 1867, the Charlottesville Chronicle, one of the most careful and conservative papers of the State in all its editorials, said: "The people of Virginia prefer military law-very harshest military law, yes even Tiberius himself" rather than the negro suffrage laws then being discussed by Congress.

The Legislature in a joint resolution, February 6, 1866, declared: "That Virginia will not voluntarily change the

8Enquirer, May 22, 1860. American Annual Cyclopædia, 1866, p. 766. 
adjustment of political power as fixed by the Constitution of the United States." February 9, 1865, the "restored government" of Viginia at Alexandria had promptly ratified the thirteenth amendment of the Constitution of the United States. ${ }^{0}$ A really representative Legislature of all Virginia had by their. resolutions of February 6,1866 , accepted the abolition of slavery as an accomplished fact. ${ }^{\circ}$ The Constitution as amended by the legislative ordinance of February 24, 1866, limited suffrage to the white male ctizens of the Commonwealth of the age of twenty-one years. ${ }^{1}$ The Legislature on January 9, 1867, unanimously in the Senate, and with one dissenting vote in the House, refused to ratify the fourteenth amendment. ${ }^{2}$ These votes of the Legislature on the different phases of the negro question indicate very accurately the prevailing sentiment in Virginia.

The white people of Virginia were in the spring of 1867 almost unasimously opposed to "immediate universal manhood suffrage," which was thrust upon the State by the congressional Reconstruction Acts. ${ }^{3}$ They never became reconciled to unqualified negro suffrage, and by the Constitution of 1902 practically disfranchised most of the blacks.

In Congress it was frankly avowed that the purpose of enfranchising the negroes was to secure the perpetual ascendency of the Republican party in the nation through the support of these black allies. ${ }^{4}$ If there had appeared

\footnotetext{
${ }^{9}$ Acts, 1865-66, p. 449.

${ }^{0}$ Acts (Alexandria) 1865, p. 30.

0 Acts $1865-66$, p. 449.

3Acts $1865-66$, p. 226.

2Acts 1866-67, p. 508; Whig, January 10, 1867; Waddell, History of Augusta County, p. 346.

BProspectus Richmond Daily Examiner November 30, 1866; App. Globe 1866-67, p. 146 .

Mr. Boyer's speech, Globe 1865-66, p. 2466.
} 
any probability at that time that the negroes would vote the Democratic ticket few will dare say that devotion to the principles of universal equality would have induced the Republican majority in Congress to put the ballot in the hands of the freedmen.

\section{CHAPTER XII.}

Edudation OF the NEgRoes From 1865 to 1867.

The statute making it unlawful for negroes on any condition to assemble for instruction in reading and writing and for religious worship conducted by a negro without the presence of a white person was not repealed until Feb. 27, 1866; yet they assembled as freely as whites, both in schools and religious meetings, for more than ten months after the close of the war, until by action of the General Assembly all restraints of this character were removed.

Many of the most thoughtful men in the State urged that the late slaves should be encouraged and assisted to secure as thorough an education as they were capable of receiving. ${ }^{5}$ They favored the education of the negroes as a matter of justice, since it was unfair to them to turn them loose as freemen to win their own support and to compete with white men without giting them an opportunity to fit themselves for the struggle. They also felt that the blacks, as ignorant and unskilled free men, would prove a serious burden and a positive danger to the State. The press of

sGeneral Howard's Report, p. 672, Messages and Documents of U. S. Government, 1866-67; General Terry's Report, pp. 1883-34, Globe 1865-66. 
the State generally advocated an earnest effort to educate and elevate them. ${ }^{6}$

Many others of the most thoughtful class felt that the blacks should be aided and encouraged in getting only such school training as would be useful to them as private persons and would enable them to pursue with success the common forms of labor and the trades to which they as slaves had been accustomed and to which they would of necessity confine themselves in the future. It was generally felt that they would not be called on to serve the State in a political capacity, and it did not seem probable that they would for many years be able to earn a living in the professions.?

A large number of the people during the first two years following the war were either indifferent to edncating the negro in any form or were positively opposed to it. Many of the more ignorant and illiterate whites were not pleased with the idea of educating and elevating the freedmen. ${ }^{8}$ Slavery, which had formerly clearly distinguished the condition of the poor whites from that of the blacks, had been swept away. They now saw the negroes free and aspiring to all the civil and political rights of the whites. Naturally they did not relish the idea of becoming the rivals of the negroes whom they despised as an inferior race, and by whom they were in turn despised as "poor white trash." This class of whites now felt that it was more important than ever before to keep the blacks sharply distinguished from the whites by artificial as well as racial 20, 1886.

"Editorial Lynchburg Virginian, October 22, 1865; Whig, August

TThis was the general feeling throughout the State. See the newspapers of the time.

8General Terry's Report, pp. 1833-1884, Globe 1865-66; General Howard's Report,' p. 655, Messages and Documents of U. S. Government, 1866-67. Only the lowest class of the whites opposed all forms of negro Bducation and advancement. 
barriers. They were therefore opposed to giving them training and culture that would render them rivals in the trades and would tend to obliterate the distinctions between the two races.

As early as October, 1861, the American Missionary Association had opened schools for negroes at Fortress Monroe. ${ }^{9}$ As the war progressed interest in their education increased in the North. Various societies, philanthropic and religious, began to raise money to send teachers to the South. These teachers appeared in Virginia in considerable numbers in the summer of 1865 . The Freedmen's Bureau generally furnished only the buildings and the material equipment. The teachers were paid from funds collected in the North by the various societies. ${ }^{0}$ Schools were opened in which nearly all the teachers were white, many of them being women from New England. During the period from 1865 to 1867 a considerable number of negroes began to teach in these schools, yet the number of white teachers in the colored schools was always about two-thirds of the whole teaching force. ${ }^{1}$ By the close of the year 1865 there were in Virginia, mainly in the southeastern part of the State, ninety schools, one hundred and ninety-five teachers, and eleven thousand five hundred pupils. $^{2}$ By the close of 1866 the number of schools and students had considerably increased. ${ }^{3}$

The officers of the Freedmen's Bureau from time to time reported that the feeling in regard to the necessity of educating the freedmen grew stronger each year. General Howard, in his report at the close of the year 1866, says

PP. 116, Virginia School Report 1871.

OFor an excellent account of the work of these schools from 1861 to 1870, see pp. 115-118 of Virginia School Report 1870.

1American Annual Cyclopædia 1867, p. 823.

2American Annual Cyclopædia, 1865, pp. 376-77.

3American Annual Cyclopædia, 1866, p. 337. There were more than 14,000 pupils in Freedmen's schools, January 1, 1867. 
there had been a noticeable change of sentiment in regard to negro schools since the war. Leading statesmen were urging the people to educate the negroes; religious conventions had passed resolutions urging upon their members the importance of giving them instruction. ${ }^{4}$

There was still some opposition to these schools by the whites. The Bureau officers constantly complained that the more ignorant element of the population continued their opposition to the enlightenment of the negro, and it seems that their complaints were well founded. Yet much of the ill feeling toward the colored schools was due not so much to an unwillingness to have the blacks educated as to the manner in which it was being done and to the persons by whom these schools were conducted. ${ }^{6}$ As has been mentioned elsewhere, a very large part of these teachers were imbued with the radical abolition ideas of the North. They believed in equality of rights and privileges for all races and colors, and encouraged a certain freedom of manner towards the whites which the whites were not prepared to tolerate from the blacks. In a short time the negroes fell in a large degree under the influence of the teachers. All this displeased the whites, who felt that the negroes were being led to expect too much in a social way, and were, at the same time, being alienated from their old friends and masters.

Another phase of this educational work that did much to disincline conservative citizens to encourage these outside teachers was that they were directing their efforts, in a very large degree, to preparing the freedmen to ask full political privileges. The prejudices engendered by two hundred and fifty years' acquaintance with the negro as a

4P. 655, Messages and Documents of the U. S.Government, 1866-67; also p. 666, Messages and Documents of the U. S. Government, 1867-68.

${ }^{6}$ Lynchburg Virginian, October 22, 1865; Whig, August 20, 1866; General Terry's Report, Globe 1865-66, pp. 1833-84; General Howard's Report, Messages and Documents of U. S. Government, 1866-67, p. 655. 
servile race would not allow the Virginians to grant this without a struggle. Yet in some of the towns the citizens from the first expressed a willingness to co-operate with the agents of the Freedmen's Bureau and the Northern philanthropic societies. Where such a feeling prevailed, the schools were soon turned over to the lncal municipal authorities with the understanding that these schools should continue for a stipulated time to receive the support from the philanthropic societies which had been given the schools before the assumption of their control by the city. Such was the case with the city of Lynchburg. ${ }^{7}$

It was freely charged by some of these teachers that the negro school buildings had been burned by the whites. The very small number of houses destroyed and the absence of evidence to implicate the whites renders it highly proba. ble that scarcely a single building was destroyed by a white incendiary during that period. ${ }^{8}$

In summing up the attitude of the whites toward negro education, toward the teachers, and in regard to renting houses, General Terry says: "In some places the people cordially approve it (the education of the freedmen). Many have taken part in it. In other places the reverse is the case-some persons coming to teach the negroes have not been permitted to rent a place, either for school or personal occupation, and it has been reported to me that teachers sent to teach the blacks have been treated with great contempt and in some places threatened."'

Many of the worthy teachers were misunderstood by the white people amongst whom they had come to labor. They therefore were not welcome from reasons before mentioned. Others of these teachers without tact and some-

7Gen. Terry's Report, Globe 1865-66, pp. 1833-34.

8P. 46, House Document No. 120, 1st Ses. 39th Congress; p. 278, Ku Klux Conspiracy, 2d Session 42d Congress, 1872.

9Globe 1865-66, pp. 1833-84. 
times without character became involved in difficulties with the whites of the community. Geuerally these brawls were not traced to their true origin, but were reported by the teachers and agents of the Bureau as marks of hostility to the education and elevation of the late slaves. Owing to the agitation of the public mind, the most insignificant disturbance was magnified into a riot. These outrages were the capital of the "scalawag," the "carpetbagger" and the turbulent negro politician on the one side; on the other side, some of the whites industriously spread abroad reports of the wildest plans and wrong-doing of the freedmen and their partisans. Chagrin at defeat, hatred toward the conquerors, hostility to the proposed new status of the negro, and opposition to the form and spirit of the education being given the freedmen, disqualified, in a large measure, the whites from correctly estimating the teachers and the schools. On the other hand the Burean agents and teach. ers interpreted any opposition to the teachers or their methods as hostility to any form of education for negroes.

It is therefore very difficult to determine what part of the whites were in principle opposed to negro education; yet it is certain that a considerable element, generally of the more ignorant class, was unwilling to see the negroes educated or elevated in any way.

The State Legislature in its session of 1865-66 and of 1866-67 made no new provision for the education of either whites or blacks. The State was so impoverished by the war that it could hardly be expected to attempt the inauguration of a public free school system for either race at that time. It is, of course, impossible to affirm positively just what would have been the policy of the whites in regard to negro education if they had been left to solve this problem. The fact that the Legislature in an act concerning apprentices, passed January 30,1866 , provided that every minor bound an apprentice should be taught not only some business or trade, but also, "reading, writing and common 
arithmetic including the rule of three," indicates clearly that the Legislature intended that in the future there should be no difference between the education given a white and black apprentice. ${ }^{0}$ By this act the fifth section of chapter one hundred and twenty-seven of the Code of 1860 was so amended as to put all appreutices, regardless of color, on absolutely the same footing in regard to education as in all other respects.

The passage of the Reconstruction Acts of 1867 took this matter out of the hands of the whites. Most of the thoughtful people had felt from the close of the war that some form of education was necessary to enable the freedmen to take their new places in society. This feeling was constantly growing amongst all classes. It is, therefore, probable that liberal provisions would soon have been made by the Legislature for their education.

OHAPTER XIII.

\section{APPRENTIOE LAWS IN VIRGINIA.}

It has been shown how completely society was revolutionized and the home life of the negroes broken up by the war. Thousands of negroes had deserted their children. Many young negroes, imitating their elders, refused work as unbecoming freemen, and lived by begging and stealing. Many white parents had died leaving their children homeless and friendless. There was during the years of 1865 and 1866 a larger number of homeless, idle children in Virginia than at any other period in her history. These young

OActs $1865-66$, p. 86. 
people were growing up in want and vice. Most of them, with no regular labor, were coming to manhood and womanhood without any trade or any disposition to support themselves. For several years after the war many young negroes were fed, clothed, and sheltered by the Freedmen's Bureau and the army around whose headquarters great throngs were congregated in idleness.

The army officers repeatedly urged the people of Virginia to adopt some fair system of apprenticeship. May 5, 1865, Geveral Halleck declared that, "For minors, not cared for by their parents, apprentice system will be introduced as early as practicable." 1 The press of the State and the army officers considered the proper education and training of orphans and homeless minors one of the most serious questions before the people. ${ }^{2}$ The army officers and Freedmen's Bureau agents feared that the people of Virginia would devise some apprentice system by which they would receive the benefits of slavery without its form. This lack of confidence in the sincerity of the people in dealing fairly with the negroes rendered more difficult the efforts to find homes and employment for the young negroes. July 15, 1865, Gen. O. O. Howard issued orders to the agents of the Freedmen's Burean that they should supervise the contracts of freedmen, but in no instance should "apprenticeship or any substitute for slavery" be allowed. ${ }^{3}$ This order was intended to prohibit only abuses of the apprentice system by which a person might conceivably be enslaved for a number of years; yet it, in its actual influence, discouraged all attempts to apprentice minors even on the most liberal terms.

1P. 1081, Serial 97, Official Records of the War of the Rebellion.

2Lynchburg Virginian, November 4, 1865; Richmond Times. May 15, August 19, 1865; p. 1216 Serial 9\%, Official Records. General Howard, Commissioner of the Freedmen's Bureau, orderer that, "State laws with regard to apprenticeship will be recognized by this Bureau, provided they make no distinction of color." Whig. October 6,1865 .

3See Geueral Howard's Order, Richmond Times, JuY 15, 1865. 
In some of the "Cotton States" during the summer of 1865 , there was some talk of the "gradual emancipation" plan and an "apprentice" plan, the purpose of which was to mitigate the bad effects of "immediate emancipation" of all the slaves. These plans never found any support in Virginia. The Richmond Times of May 15, 1865, discussing them, says, "The edifice of our future greatness can be built on free labor, and Virginia has something better in store for her than to play the dry nurse for two or three hundred thousand negroes for the next half century."

Nevertheless it was realized by all that something had to be done to teach the throngs of idle young negroes hab. its of industry and force them to earn their bread. November 4, 1865, the Lynchburg Virginian says, "Apprenticeship to prevent young negroes from growing up in idleness and vagrancy should be a settled policy to be regulated upon some system of justice and fair dealings between both parties." It was generally felt that the two most important questions that would come before the Legislature to meet in December, 1865, would be the vagrant and minor negro questions.

The Code of 1860 provided for "binding out" or "appreuticing minors under certain conditions." 4 It may be well to remark that nearly all the apprentices prior to 1860 were white, as there was in the whole State only a com. paratively small number of free negroes. The word "master" as used in the statute of 1860 was not understood to imply any ownership of the "apprentice" or "bound person," but was a survival from the time when all men who held "apprentices" or "bound persons" were masters of the trade or calling which the apprentice was to be taught. It has been said that the use of the word "master" in the statutes of 1866 in regard to apprentices indicates a purpose on the part of the Legislature to place 
the "bound person" in the relation of a slave to his employer. Such is not the case, for in every instance in which the word "master" occurs in the Acts of 1866 and 1867 it is taken from the Code of 1860 , which was enacted to regulate the relation of "master" and "apprentice" when almost all the apprentices were white. It has never been claimed that there was any desire to enslave or wrong the wbite apprentices.

An "apprentice," according to the statutes of Virginia, was a minor bound until twenty-one years of age in the case of a male, and to eighteen years in the case of a female, to perform services for a master, and to receive in turn instruction in his trade or occupation. There was nothing servile in apprenticeship, as will be seen by an examination of the statutes regulating and defining the rights and duties of both master and apprentice. The Constitution adopted at Alexandria in the spring of 1864 declares: "Courts of competent jurisdiction may apprentice minors of African descent on like conditions provided by law for apprenticing white children."

The Legislature of "restored Virginia" at Alexandria enacted no legislation touching this question. This explicit constitutional provision was sufficient, since the Code of 1860 defined on what conditions white children could be apprenticed. When the Legislature of Virginia met at Richmond in December, 1865, it took up the minor negro question. After nearly two months it was decided to make only ove change in the "master and apprentice" statutes of the Code of 1860 . By this Code the master was not required to teach a "free negro" apprentice "reading, writing and arithmetic," which were required to be taught white apprentices. With this single exception the laws regulating white and black apprentices were the same. This section in the Code of 1860 real as follows: "The writing by which any minor is bound an apprentice, shall specify his age and what art, trade or business he is to be 
taught. The master, whether it is expressly provided therein or not, shall be bound to teach the same, and, unless the apprentice be a free negro, shall be bound to teach him reading, writing and common arithmetic, including the rule of three." It was amended January 30, 1866, so as to read: "The writing by which any minor is bound an apprentice shall specify his age and what art, trade or business he is to be taught. The master, whether it is expressly provided therein or not, shall be bound to teach the same, and shall also be bound to teach him reading, writing and common arithmetic, including the rule of three."

This was the only change made in the apprentice laws by the Legislature in its session of 1865-66. By this amendment white and black apprentices were put absolutely on an equality.

January 28, 1867, at its secoud session, the Legislature passed "an act concerning the authority of employers over minors in certain cases" which read as follows:" "That whenever a minor is held to service or labor of any kind, for a period not less than one month, the employer may exercise the same authority, control and discipline over the said minor as are now exercised by a master over an apprentice, unless it shall be otherwise agreed in the contract for the employment of said minor."

The purpose of this act was to give the employer the same rights to control and discipline a minor under contract for a longer period than one month as were legally exercised by the master over an apprentice. This statute conferred on the employer no right to overwork, underfeed or otherwise abuse the minor, since the "master and apprentice" laws defined very strictly the rights and obli-

5Code of Virginia, p. 585.

BActs 1865-66, p. 86.

7 Acts $1866-67$, p. 567. 
gations of master and apprentice and provided legal remedies for the redress of any grievance of either party. ${ }^{8}$

The letter of this act applies to whites and blacks without distinction; jet it was enacted to give white employers more complete control of the young freedmen, who, according to all accounts, were at that time a very unreliable class of laborers, and very little inclined to respect contracts and the rights of their employers.

In 1865 and 1866 the young negroes were constantly making complaints to the agents of the Freedmen's Bureau that their white employers were "infringing upon" their liberty by "whipping" them or using "harsh language" to them. Often the Bureau agents gave a ready ear to these reports of outrages, however poorly attested. Respectable men who had "infringed upon the liberty" of jouthful "Afro-Americans" by using a switch on their backs or by not addressing them "politely" were notified to appear and confront their accusers before the Freedmen's Court. This act of January 28, 1867, had a tendency to diminish the number of such cases by legalizing so far as a State law, at that time, could legalize anything, the power of the employer to discipline his young employee.

This statute conferred on the employer no unusual power, but simply stated that he could lawfully exercise upon a minor, under contract for labor for a longer period than one month, the rights of a master over an apprentice, unless it was provided in the contract for such service that he was to enjoy no such right of control. It does not appear that this act was ever abused, since by its own terms it did not go into effect until May 1, 1867. Before that time the Reconstruction Acts had reduced Virginia to a military district and had suspended to a great extent the operation of all the State laws.

8Code of Virginia, pp. 585-587. 


\section{OHAPTER XIV.}

\section{Negro Marriages.}

The immediate effects of emancipation on the marital relations of the negroes was disastrous. The results of the war had freed them not only from slavery but also from all forms of restraint, marriage among the rest. Hundreds and thousands of marriages were dissolved at once without formality, and new ones formed also without formality. ${ }^{9}$ Some negroes who had been "refugeed" away from home on the approach of the Union forces or who found themselves for any reason separated from their wives, decided, at the close of the war, that it was "cheaper" to marry where they were than to return to their old homes to their former wives.

Thoughtful people felt that this laxity was a serious peril to the future of the black race. The army officers requested clergymen and all others empowered to celebrate the rite of matrimony to call the attention of the negroes to the propriety of regular marriage. ${ }^{0}$ The Freedmen's Bureau made vigorous efforts to "re-establish the sanctity of the marriage relation amongst the freed people." "The various churches strove to impress them with the necessity of fidelity to their marital obligations and urged them as Christians and freedmen not to abuse their liberty by running into licentiousness and promiscuous intercourse. The efforts of the army officers, Freedmen's agents, and ministers were fairly effective. ${ }^{2}$

YRuffl, The Negro'as a Political and Social Factor, pp. 18, 17.

'Gen. Halleck's Order, Serial 9i, Official Records of the War of the Rebellion, p. 1221.

1Messages and Documents of U. S. Government, 1866-67, p. 665.

${ }^{2}$ Rev. S. A. Harris, a colored minister, applied to the Court of Hustings in Richmond for license authorizing him to perform the marriage 
Before the war there had been no legal provision for the marriage of negroes in Virginia. No license was issued for their marriage and no record was made of the simple ceremony by which they were declared man and wife. These marriages were solemnized by negro ministers and were respected with a considerable degree of fidelity. As has already been said, these nnions were dissolved with great recklessuess at the close of the war. The Legislature felt that something must be done to give greater force and sanctity to the domestic relation among negroes. February 22,1866 , an act was passed providing for the marriage of colored persons in the future on the same conditions as were prescribed for whites. ${ }^{8}$ By this act a license issued by a county or corporation clerk was necessary. After the marriage a record of the whole proceeding was to be made in the clerk's office.

During the years 1865 and 1866 the military authorities and the Freedmen's Bureau agents had done much to encourage the negroes to marry according to prescribed forms, and had made a record of all such marriages as had been solemnized by their authority or acknowledged in their presence. Many negroes had been married under the direction of these officers. Many others who had been "cohabiting as man and wife" for years appeared before them and on the payment of a fee of twenty-five cents were given a certificate of their relation as husband and wife. In April, 1867, the General Assembly instructed the Governor to obtain from the United States authorities the records of all such marriages and acknowledgments by negroes and to cause them to be deposited with the clerks

ceremony, but was refused on the ground that there was no law for granting such license. Enquirer, Nov. 15, 1865. The Freedmen's Court in Richmond authorized the issuance of license to negroes wishing to get married. Enquirer, Dec. $11,1865$.

3Acts 1865-66, pp. 85-86. 
of the several counties of the State "to preserve evidences for legitimatizing the offspring of such marriages."

By these acts all marriages before the war were legalized; the children of such unions were declared legitimate. The records of marriages contracted in the unsettled period following the war were preserved, and the marriage of colored persons in the future was provided for on the same conditions as were prescribed for whites.

\section{CHAPTER XV.}

\section{INSURREOTION.}

During the war the conduct of the slaves toward their masters' families was in the highest degree praiseworthy. At the close of the war there was very little fear that the negroes would make insurrection against the whites. Only two uprisings of any importance had ever occurred in the State; namely, Gabriel's attempt near Richmond in 1800, which amounted to little; and Nat Turner's in Southampton county in 1831, in which fifty-five persons lost their lives. ${ }^{5}$ These occurrences excited temporarily great terror. In 1860 a generation had passed without another such attempt, and the rural whites dwelt in confident security in the midst of a colored population numerically greatly superior in a large part of the State.

Before the war it had been feared that horrible excesses would follow the immediate emancipation of the

${ }^{4}$ Acts $1866-67$, p. 951.

5Minor's Institutes, Vol. I, p. 169. The number slain is variously reported. 
slaves. Their exemplary conduct during the war had almost entirely dissipated these fears. In a few sections there was, in 1865 and 1866 , some apprehension that the armed freedmen would rise against the whites. General Terry was urged to disarm them, which he declined to $\mathrm{do}^{6}$ No uprising followed. There were frequent collisions between white and black individuals, but there was no insurrection of one race against the other.

The Code of 1860 provided the death penalty for inciting negroes to iusurrection. ${ }^{7}$ There was no penalty for inciting whites against negroes. The Legislature, February 9, 1866, enacted: "That the fourth section of chapter one hundred and ninety of the Code of Virginia for eighteen hundred and sixty be amended and re-enacted so as to read as follows, to wit:

"\$4. If any person shall conspire with another to incite the colored population of the State to make insurrection, by acts of violence and war, against the white population, or to incite the white population of the State to make insurrection, by acts of violence and war, against the colored population, he shall, whether such insurrection be made or not, be punished by confinement in the penitentiary for not less than five nor more than ten years."

This act repealed all special punishments for inciting negro insurrections, and provided a penalty of from five to ten years in the penitentiary for inciting either whites or blacks to insurrection. The comparative mildness of the penalty indicates that the Legislature apprehended litile danger from uprisings of one race against the other.

'General Terry's testimony, Congressional Globe, 1865-66, p. 1834.

'Code of Virginia, p. 783.

8 Acts 1865-66, p. 81 . 


\section{CHAPTER XVI.}

\section{Separate Churohes for Negroes.}

Before the war it was unlawful for negroes to meet for religious worship conducted by a colored person unless a white man was present. ${ }^{9}$ This statute was frequently disregarded. There were many negro preachers who were respected by their masters and who exerted a wholesome influence on the slaves. ${ }^{0}$ They were illiterate but fervent and frequently pious. It was also unlawful for negroes to assemble for the purpose of being instructed in reading and writing. Nocturnal meetings of any kind were unlawful. After the war the whites offered no objection to the education of negroes or to religious mettings conducted by negroes without any supervision of whites.

Almost all slave owners gave more or less attention to the religious and moral growth of their own slaves. The plantation of every pious master had its Sunday school, in which the negroes were instructed by enthusiastic itinerant white preachers and frequently by the pious women of the family. Many negroes were members of the same churches as the whites. A place was always reserved for them, sometimes in the body of the church, but more often in the galleries. In some places separate churches were built for them by subscription of their masters. Many of the ablest white winisters preached to these negro congregations from time to time.

There were no separate ecclesiastical organizations for blacks. Most of the negro church members were Baptists, but they were not found in that church alone. After the close of the war most of the colored members withdrew

${ }^{4} \mathrm{Code}$, p. 810.

oOlmsted, Seaboard Slave Stater, Vol. I, p. 119. 
from the Baptist Church and formed a separate organization with their own church buildings and preachers. ${ }^{1}$ In this they were encouraged by the whites. Before the close of 1866 the colored Baptist churches of the South formed a number of associations which put themselves in connection with the Northern Baptist societies. In the American Baptist (African) Missionary Convention which met in Richmond in August, 1866, nearly all the Southern States were represented. ${ }^{2}$ Schools were maintained at Alexandria, Culpeper, Fredericksburg, Williamsburg, Portsmouth and Richmond, in which special attention was given to training colored ministers. ${ }^{8}$

The General Assembly of the Southern Presbyterian Charch, November 15, 1566, considered the relation of the freedmen of that church to the white members. In the various synods throughout the South there were earnest discussions in regard to the fraternal standing of the colored men in the Presbyterian Church. By some it was urged that negroes, from the nature of Christianity, were entitled to become deacons, ruling elders, or ministers of God, and that in the church sessions and assemblies they were entitled to "perfect equality." Others warmly opposed this view as leading to miscegenation of the races."

In the first general conference of the Methodist Episcopal Church, South, after the war, in April, 1866, at New Urleans, it was provided that the negroes could be organized into separate congregations and have their own preachers, presiding elders, and other officers. ${ }^{5}$

In reconstruction days the negro preachers were prom-

IPeyton, History of Augusta Connty, p. 88; pamphlet by F. G. Ruffin (Randolph \& English, Richmond).

${ }^{2}$ American Annual Cyclopædia, 1866, p. 57.

${ }^{3}$ American Annual Cyclopædia, 1867, p. 87.

4 American Annual Cyclopædia, 1866, p. 625.

'American Annual Cyclopædia, 1866, p. 491. 
inent spokesmen of their race. Few of the blacks could read, all were excited and inquisitive about their future condition. The oratory of the radical leaders and colored preachers was the chief source of political information and knowledge that they trusted. The ministers were confident, fervid, and wordy. Many of them were immoral and neglected the Gospel for politics and sociology.

Within a few years after the war practically all of the negroes withdrew from all the white ecclesiastical organizations, and formed numerous denominations entirely independent of white control or direct influence. A great multiplicity of church societies sprang up in each of these sects. The social side of church life was highly developed. The church building with its festivals, social meetings, and revivals became the social center of the colored community. The members contributed liberally to the building of the churches and to the support of their ministers and church enterprises.

\section{CHAPTER XVII.}

\section{EFFECTS OF THE RECONSTRUCTION ACTS.}

The Reconstruction Act of Congress, March 2, 1867, was an attempt of the radicals to force the Southern people to recognize the civil and political equality of the colored race. This act virtually destroyed the government of Virginia and changed the State into Military District Number One, of which General John M. Schofield of the United States army was made commander. ${ }^{6}$ The negroes were

"In the main Gen. Schoffeld discharged the duties of his office with tact and sympathy. Through him Virginia was spared much that other states suffered. See his autobingraphy, Forty-six Years in the Army, Chapter XXI, for his account of his administration. 
enfranchised and the last vestiges of their inferiority, civil and political, were wiped out by Federal legislation.

It was felt by many that the traditional influence of the old masters would lead the enfranchised freedmen to vote with the whites. ${ }^{7}$ John M. Botts favored enfrauchisement of the negroes as right in principle but opposed it as inexpedient since he believed they would vote with their old Democratic masters.

Negroes attempted to vote in a municipal election in Alexandria early in March, 1867. ${ }^{8}$ About fourteen hun. dred votes were presented by the negroes and were declined by the election officers. This denial was severely criticised in the North and in Congress. The whites withheld the ballots from the blacks as long as it was possible for them to do so. After Congress had enfranchised the freedmen many of the leading newspapers urged the whites to strive to maintain their influence with them and thereby prevent their falling under the leadership of the radicals who had for some time been growing in inflnence with them. ${ }^{9}$

Many of the negroes announced that they would vote with the whites. In most cases they were ostracised and intimidated frequently by the women of their race or by radical organizations such as the Union League. Democratic negroes were denied membership in many churches. It was feared that a general collision of the races would be precipitated by the ill advice of incendiaries and radical white leaders, amongst whom Rev. J. W. Hunnicutt, the editor of the radical newspaper, the Richmond "New Nation," and Judge Underwood, of the Federal Court, were ivery prominent and influential. ${ }^{\circ}$

7Richmond Dispatch, March 23, 1867, April 5, 1867; Whig, March 6, 23, April 1, 1867.

8Richmond Enquirer, March 8, 1867.

9Richmond Enquirer, May 18, 21, 1867 ; Richmond Republic, July 6, 7, 1865; Richmond Whig, April 1, 1867.

ORichmond Enquirer, March 26, May 18, 1867; Dispatch, June 20, 1867. 
The representative newspapers advised the negroes to remain friendly with their old masters and not allow themselves to be ruined by talk and politics. ${ }^{1}$ At the same time the white people were urged to explain to the negroes their rights and duties as voters, but it was everywhere felt that honest, conscientious citizens could not bid against Hunnicutt and the radicals for the vote of the negroes. The Union League was the chief agency by which the negroes were organized and pitted against the whites. This organization was peculiarly adapted to the character of the blacks. In it they were instructed in the privileges and duties of citizenship and special stress was laid on their obligation to oppose the whites and to support the Republican party which had given them the ballot. ${ }^{2}$ It early became manifest that the negroes would vote solidly with the radicals. ${ }^{3}$ More than ninety-three thousand blacks voted in the election 'in October, 1867; only six hundred and thirty-eight voted with the white conservatives.

The Freedmen's Bureau officials urged all negroes to register and vote for delegates to the convention which was soon to be called to frame a State constitution that would give the negroes full civil and political equality. ${ }^{4}$ Almost every male negro of legal age promptly registered. Army officers and Burean agents were given the preference in making appointments of registrars.

The whites were apathetic. Many neglected to register although the leading men and press urged all to register and vote. ${ }^{5}$ Many were so disgusted at negro suffrage that they declared that they wonld never vote again.

IRichmond Enquirer, April 2, 27, 1867; Whig, April 1, 1867.

2Documents Relating to Reconstruction, edited by W. L. Fleming.

3Richmond Enquirer, May 24, 1867.

TRichmond Enquirer, June 1, 1867.

5Richmond Enquirer, June 17, 1867; Whig, March 7, 1867.

6Richmond Dispatch, April 5, 1867. 
This was very unfortunate as it made it easier for the radicals and negroes to dominate the State for several years. About forty-four thousand registered white voters neglected to vote in the election of October, 1867. Congressional acts excluded many Confederate soldiers from roting and almost all of them from holding office, since an officer was required to take the "test oath" that he had not engaged in armed revolt against the United States, or given "aid or comfort" to the Confederate cause.

Many declared that negroes were not eligible to office ander the Reconstruction Acts. ${ }^{7}$ The colored inhabitants of Alexandria had nominated uandidates for office March $1,1867 .{ }^{8}$ In the summer of the same year a considerable number of them were nominated and in October twenty-five were elected members of the Constitutional Convention. Their right to hold office was soon generally recognized.

The passage of the Reconstruction Acts in the spring of 1867 encouraged anew the negroes to hope for the confiscation and division of the lands of the Confederates among the late slaves. In September, 1866," "radical emissaries" in Buckingham and adjoining counties urged the negroes not to work for the whites and to assert their claims to the land. ${ }^{\circ} \quad$ All confiscatory schemes were ardently supported by most of the blacks. Nevertheless most of the Republican leaders in Virginia in the summer of 1867 discouraged the negroes in their clamor for confiscation. Many farms occupied by freedmen were restored to the owners in a comparatively short time after the war.

It was more difficult to secure negro labor after March, 1867, than it had been before, inasmuch as about all negroes gave themselves up to politics. ${ }^{\circ}$ After registration began

TRichmond Dispetch, April 13, July 11, 1867.

8Richmond Dispatch, March 6, 1867.

ORichmond Whig, Bept. 11, 1866.

ORichmond Enquirer, April 18, 1867; Dispatch, July 8, 1867. 
they became more demoralized than they had ever been before that time.

Encounters between whites and blacks became more frequent. In May an agitator was arrested on the charge of inciting the negroes to acts of violence and insurrection. He urged them to assert their claims to all the rights and privileges enjoyed by white people in any Northern state, including the right to ride in street cars and to sit in any churches and theatres. Negro riots such as occurred in Richmond in May, 1867, alarmed the people. It was feared that the relations of the races would continually grow worse. ${ }^{1}$ There was much reckless talk. A delegate to the Philadelphia Convention in September, 1866, said that the negroes must be drilled and organized for fighting the whites. ${ }^{2}$ He prophesied a "rich San Domingo" in the South when "the rebels attempt to rule the blacks." Yet many influential negroes strove to avert any ill feeling between the races. ${ }^{3}$ The relation of the races became more strained and unsatisfactory than at any previous time in the history of the State.

Many white men felt that it was not prudent or patriotic to stand haughtily apart and allow the negro voters to fall under the influence of radicals and self-seekers to the hurt of every interest of society. They denied the wisdom or constitutionality of the means by which the negroes had been made citizens and voters but considered it wise to recognize actual conditions and to strive to neutralize as far as possible the baneful influence of selfish leaders on the negroes. These whites soon found it impossible to co. operate with the black voters who suspected their motives and implicitly trusted the "scalawags," "carpetbaggers," and their own leaders.

1Richmond Enquirer, May 11, 1867.

${ }^{2}$ Whig, Sept. 6, 1866.

aEnquirer, Mey 10, 1867. 
A wide difference of opinion appeared as to what course the General Assembly should pursue. Some urged that it should call a constitutional convention and take steps to put into effect the provisions of the Reconstruction Acts. A large and respectable group opposed this course and favored a policy of "passivity." 4 They argued that the people should avail themselves of the delay allowed by the law in hope that the State might yet be spared the shame and humiliation of universal negro suffrage imposed upon it by the Federal Government. The newspaper discussions of this question were very acrimonious.

A State convention, called by the Republican Committee, met in Richmond April 17, 1867.5 Of the two hundred and ten delegates present one hundred and sixty were negroes. About one half of the State was represented. Very radical resolutions were adopted. Confiscation was demanded by almost all the negro delegates. Some of the speeches were of a very inflammatory character. The negroes at this time were completely under the influence of Hunnicutt. Many respectable Republicans were dissatisfied with the radical policy of Hunnicutt and the negroes. ${ }^{6}$

About this time efforts were made to form a Republican party in Virginia less radical than the Hunnicutt organization. The Richmond Whig became the advocate of this movement. Late in April a convention in Petersburg formulated a platform which, it was hoped, was radical enough to meet the approval of the North and not too radical to win the support of the conservative Republicans of Virginia. ${ }^{7}$ This platform did not receive much popular

The Enquirer was the leader of the "passivity" group. Most of the other leading newspapers farored a prompt acceptance of the provisions of the Reconstruction Acts.

sEnquirer and Whig, April 18, 1867.

oWhig, April 5, $186 \%$.

This platform demands * * "that the political power of the State shall henceforth be possessed and exercised by white and black alike; 
support. Governor Peirpont, John M. Botts and other strong men had always denied the regularity and legitimacy of the Richmond Convention. The Petersburg Convention accepted Botts as leader of the movement against Hunnicutt and the extreme radical organization.

A call for a new convention at Charlottesville to organize the Republican party in the State was signed by more than three hundred men. ${ }^{8}$ Many of these were old line Whigs of character and influence. Hunnicutt and the radicals ignored this call.

The Reconstruction Committee in Washington now intervened. Through its influence the "Union Leagues" of some of the great cities in the North undertook to bring about harmony between the radicals and conservatives. In June, 1867, about fifty men representing the two factions met in Richmond to try to bring harmony amongst the friends of the negro. Judge Underwood, Senator Wilson, John M. Botts, J. W. Hunnicutt, and John Hawxhurst were prominent in this meeting. ${ }^{9}$ It was decided to recall the call for the Charlottesville convention and to call a convention at Richmond, August 1, to formulate a party platform. Richmond was at this time the center of radical influence. On the whole, Hunnicutt and the radicals had triumphed over Botts and the conservatives.

About this time a morement for coalition between the whites and the blacks appeared in the State. July 1 many of the leading citizens, socially and politically, of Albemarle county, met in Charlottesville to consider the wis-

\footnotetext{
* * that a new constitution shall be framed which shall provide that all men, white or black, without reference to previous conditions of servitude, shall be perfectly equal before the laws, both in respect to political privileges and power and of civil rights; and that all laws creating distinctions or differences of any sort between persons of different races shall be unconstitutional, null, and void."

8Enquirer, May 21, 1867.

PEnquirer, June 19, 1867.
} 
dom and practicability of "co-operation" with the convention called to meet in Richmond, August $10^{\circ}$ They expressed a desire to "co-operate" with the Republican party, and forty-six delegates were appointed to represent them in the Richmond convention. Practically all these "cooperators" had been active and consistent supporters of the Confederacy, and would have won for the Republican party the support and confidence of much of the best white element if they had become identified with that organization. Other counties decided to "co-operate," and sent as delegates some of their most distinguished eitizens.

The "co-operators" accepted negro suffrage as an accomplished fact. They hoped to secure the support of the freedmen and to leaven the radicalism of the Republican party. In such a coalition the leaders would have been white men. This plan did not commend itself to the negroes, who demanded a "fair division of all offices," and declared that wherever two men were elected or appointed to office one of them must be a negro. ${ }^{1}$ Hunnicutt and the radicals did not welcome the overtures of the "co-operators."

The convention met in the African church, in Richmond, on the appointed day. The negroes thronged around the church as early as seven o'clock in the morning and poured in and filled the building when the doors were opened at eleven. About two thousand negroes, Mr. Botts, and the white "co-operator" delegates were left outside. This convention was made up of negroes, except the fifty white delegates who had attended the April convention. Hunnicutt addressed the "mass convention" in the church. He said that the only work before the meeting was to "endorse" the April platform." It was promptly "en-

OEnquirer, July $3,1867$.

1Charlottesville Chronicle, July 2, 1867.

2Enquirer, August 2, 1867. 
Negroes and Their Treatment in Virginia, 1865-67

dorsed." A motion to allow Botts to address the convention was lost almost unanimously.

Many of the country negro delegates were not admitted into the church. These, with the throng of negroes around the church, repaired to the Capitol grounds and were addressed by John Hawxhurst, a bitter radical. The "cooperators" were huddled together on the outskirts of the throng. Botts and the conservative Republicans were ignored. The "co-operation" movement had failed. The negroes had definitely declined the overtures of the whites and committed all to the radical leaders. This triumph of the radicals and negroes disgusted and discouraged the whites; who had hoped that the negroes could be induced to accept the leadership of their former masters. After this some of the Union Leagues refused to admit white men as members."

An election was ordered for October 18-21 to determine whether a constitutional convention should be called and to elect delegates to this convention if the popular vote should favor it. The campaign was energetically conducted by the radicals. Many of the negroes gave themselves up completely to attendance upon political meetings and discussions of politics. Many of them were nominated for office, about one-third of the radical Republican nomi. nees being black. In Richmond the radicals nominated three whites and two blacks.

The equality of all men before the courts, equal civil and political rights for both races, free schools for all classes and colors, and the right of negroes to hold any office were leading features of the radical platform."

The total registration of voters was nearly two hun. dred and twenty-six thousand; of this number about one hundred and twenty thousand were white and almost one

sDocuments Relating to Reconstruction, edited by Fleming, No. 8, p. 4.

IEnquirer, April, 19, 1867. 
hundred and six thousand were colored. Nevertheless in the election the blacks cast over seventeen thousand more ballots than the whites. About forty-four thousand registered white voters had failed to vote, but only about twelve thousand seven hundred registered negroes remained away from the polls. Of the one hundred and five delegates to the Constitutional Convention, the radicals elected seventytwo, of whom twenty-five were negroes, and twenty-seven were from other states and foreign countries. Only about six hundred and thirty-eight negroes voted with the whites. This shows how completely the radicals had won them, despite the efforts of their old masters to influence their ballot. There was a majority of about forty-five thousand in favor of calling a constitutional convention. The radicals were jubilant and confident of their future. The negroes were almost beyond control with joy at their triumph. The white conservatives were dismayed by their overwhelming defeat at the polls.

The Constitutional Convention assembled in Richmond December 3, 1867. This was the first time in the history of the State that negroes sat as members of a legislative body. Dr. Thomas Bayne, Willis A. Hodges, and Lewis Lindsay were the most prominent and influential negroes in the convention.

The State had been revolutionized. The old political leaders were absent. The old dominant class had lost control. Negroes and their radical friends had met to frame a Constitution for the Old Dominion.

Many negroes insisted that all social distinctions of race should be removed by law and custom. In Nansemond county, in June, 1867, a negro meeting adrocated negro equality in every respect and female suffrage. ${ }^{5}$ Lewis Lindsay, a colored leader, in a speech at Charlottesville in July, 1867, claimed social equality as a right of the

sRichmond Dispatch, June 18, 1867. 
negroes. ${ }^{6}$ Similar demands were made by negro leaders and radicals about this time in many parts of the State. The editor of the Petersburg "Index" is quoted as saying: "We have never seen, nor do we know, why a white man who wishes to marry a colored woman, or a white woman who wishes to marry a colored man, should be restricted in the caprice."

It was claimed by some that the Petersburg platform favored intermarriage between the races. ${ }^{8}$ Nevertheless many negroes opposed any agitation for social equality, and were content for the time being to make sure of civil and political equality and to trust the future for other privileges. ${ }^{9}$

The whites feared that the radical doctrinaires would attempt by some means to enforce social equality as well as political and civil equality. ${ }^{\circ}$ Social equality of the races was, of course, never more than a dream of radicals and enthusiasts without the slightest possibility of realization. Most of the white people ceaselessly fought it in every form and tendency.

Civil and political equality of the negroes was guaranteed by the constitution framed by the convention that assembled in Richmond, December, 1867. The two races continued to stand apart socially. The instinct of the white race is against social equality with blacks. Neither defeat in war nor triumph of radicalism in peace could overcome the determination of the whites to resist social equality and to preserve racial integrity.

BCharlottesville Chronicle, July 2, 1867.

7Richmond Enquirer, May 6, 1867.

8Richmond Enquirer, May 4, 1867.

${ }^{9} \mathrm{Whig}$, May 28, 1867.

'Richmond Enquirer, May 6-10, 1867. 


\section{CHAPTER XVIII.}

\section{Summary and Conoluston.}

The negroes in the part of Virginia west of the Blue Ridge were only about fifteen per cent. of the entire population of that section. They were considerably in the majority in the rest of the State. The negro problem has, therefore, never been so serious a question in the Valley and Southwest as in the Piedmont, Southside and Tidewater sections.

In 1865 the people of Virginia, almost to a man, accepted the unconditional emancipation of the slaves as the most patent result of the war. The whites did not hold the negroes responsible for the events of the war or their emancipation. The negroes at once asserted their freedom and for a few years were greatly demoralized by their changed condition. The Freedmen's Bureau agents, the Northern teachers, the "scalawags" and "carpetbaggers" were, on the whole, disturbing forces and prolonged and aggravated the transitional period from slavery to settled freedom.

During this period a system of free contract labor was developed. The effort to fix wages by common agreement amongst the farmers was a failure. There was little opposition to renting or selling land to negroes. The negroes, however, did not, in most cases, prove successful renters. Considerable numbers of freedmen bought real estate in the two or three years immediately following the war. Colored men never experienced any difficulty in buying land if they had the money to pay for it.

Business was prostrated; money was scarce; the number of laborers was excessive; wages were therefore low.

In the minds of the freedmen idleness and freedom were synonymous. The rather severe vagrancy laws enacted 
by the Legislature in 1866 were not attempts to re-enslave the negroes or to minimize their freedom but were intended only to check the vagrancy and put the idle freedmen to work. This statute was annulled by General Terry within a few days after its enactment. It is, therefore, impossible to say what would have been its practical working; yet it is not probable that this vagrant act would have been seriously abused. On account of the vagrancy and unreliability of negroes as laborers it was found necessary to enact a contract law. The provisions of this act were not severe, and the consequences to a negro of its violation were only indirect. Every vestige of the old slave laws was repealed in 1865 and 1866.

The number of outrages on negroes in Virginia from 1865 to 1867 was small. There were, however, many common brawls and personal encounters between whites and blacks, but no more than were naturally to be expected in a population of twelve hundred thousand, of whom five hundred thousand were excited and insolent freedmen. A considerable number of these brawls and contests arose from the insolence and insubordination of the negroes, which the whites would not tolerate. In disputes abont money or property the negroes never experienced any diffculty in securing full justice. In common cases of assault and battery and in more serious criminal cases white courts would not always convict white men, if it was alleged that the negro had been saucy or insolent toward his white assailant. The negroes were generally given something like the maximum legal penalties for such offenses as theft, burglary and arson. The case of Dr. Watson and a few others created the impression in the North that the courts of Virginia did not protect the freedmen. Such cases were in reality extremely rare.

In the summer and fall of 1865 , before the old free negro laws had been repealed, the negroes by common consent and the decisions of the courts came into about all the 
civil rights of white men. By the legislative acts of January and February, 1866, all special punishments and court proceedings applicable to negroes were repealed; and they were thus put on an equality in this respect with white men. In 1866 they were, by act of the Legislature, declared competent witnesses in all cases in which the interest of any colored person was directly or indirectly involved. The whites were bitterly opposed to the enfranchisement of the negroes, and accepted it only as it was forced upon them by the United States Government.

A large majority of the whites favored the education of the negroes in such ways as would fit them to become more efficient laborers and artisans, but opposed both the method and aims of the Northern teachers who were teaching the negroes to expect full political rights and to oppose their former masters.

The apprentice laws of this period were the old apprentice laws of the Code of 1860 , so amended as to apply to whites and blacks alike. The Legislature declared legitimate the offspring of all unions of colored persons before the war, and provided for the marriage of negroes in the future on the same conditions as whites.

From this survey of the condition of the negroes from 1865 to 1867 it is seen that the relation of the whites and blacks was during that period about as cordial as could have been expected; that they were adapting themselves to their new conditions; that the feeling of confidence and good will between the two races, although temporarily shocked by the events attending emancipation, was reasserting itself during the first year following the close of the war; that the laws had been so amended and modified as to secure for the freedmen all the civil rights and the most important political rights enjoyed by the whites.

The Reconstruction Acts enfranchising the negroes and the other Federal legislation in their interest destroyed the confidence and good feeling that had existed between 
the two races and arrayed them in a bitter contest for the political control of the State. In the election of October, 1867, the negroes and radicals were successful. Of the one hundred and five delegates elected to frame a constitution for the State seventy-two were radicals. Of this number twenty-five were negroes. The blacks attained full civil and political equality but were unable to secure social equality. These struggles engendered political and racial passions and antipathies that have not subsided after a generation. 


\section{BIBLIOGRAPHY.}

\section{Publio Records and Doouments.}

of the United States Government.

Congressional Globe, 1884-67.

Census Reports, 1860 and 1870.

Reports of the Department of Agriculture.

Annual Reports of the Secretary of War.

Statutes of the United States.

House Documents.

Offeial Records of the Union and Confederate Armies.

Messages and Documents of the United States Government, 1866-71.

Ku Klux Report, (Report of the Joint Committee of Congress on the Conditions in the Late Insurrectionary Btates, submitted at the 2nd Session of the 42nd Congress, 1872).

Of the State of Virginia.

Code of 1860.

Acts of the Restored Government, 1863-65, (Alexandria).

Acte of General Assembly, 1865-67.

Annual Reports of Virginia, 1870-71.

\section{NEWSPAPERS,}

Richmond Times.

Richmond Enquirer.

Richmond Dispatch.

Lynchburg Virginian.

Charlottesville Chronicle.

Richmond Whig.

The Republic. 
Historioal. WORKS AND CoMrendi, PampHLets, ETO.

American Annual Cyclopadia, Appleton \& Co., Hew York.

Tribune Almanac, New York.

Blackwood's Mragazine, American Edition, Now York.

Ruffin, F. G., The Negro as a Political and Social Factor, Richmond, 1888.

Stuart, A. H. H., A Narrative of the Leading Events of the First Popular Movement in Virginia in 1865, to Re-establish Peacefui Relations between the Northern and Southern States, end of the Subsequent Efforts of "the Committee of Nine," in 1869.

Page. Thomas N., Atlantic Monthly, September, 1901, Boston. The articles on Reconstruction in the Atlantic Monthly in 1901 are valuable studies of the different phases of the negro question.

Bruce, Pbilip A., The Plantation Negro as a Frecman, Now York, 1889.

Sommerville, C. W., A Dissertation on $R$. G. Harper, Johns Hopkins University, 1899.

Woolley, E. C., The Reconstruction of Georgia, Columbia University Press, 1901.

Ballagh, J. C., History of Slavery in Virginia, Johns, Hopkin. Press, 1908.

Herbert, H. H., Why the Solid South.

Blaine, J. G., Twenty Years in Congress, Norwich, Conn., 1884.

Bancroft, F. A., The Negro in Politics, New York, 1885.

Waddell, Annal's of Augusta County, Staunton, 1902.

Peyton, J. L., History of Augusta County. Staunton, 1882.

Dunning, W. A., The Civil War and Reconstruction, Now York, 1898.

McCarthy, Lincoln's Plan of Reconstruction, Now York, 1901.

Summers, L. P., History of Southwest Virginia, Richmond, 1803. Minor, J. B., Minor's Institutes, Vol. I. Richmond, 1875.

Helper, H. R., The Impending Crisis, Now York, 1857.

Schofeld, J. M., Forty-six Years in the Army, Now York, 1887.

Collins, W. H., The Domestic Slave Trade of the Southern States, Now York, 1804.

Documentary Bistory of Reconstruction, edited by W. L. Fleming, Cleveland, 1906. 
126 Negroes and Their Treatment in Virginia, 1865-67

Du Bois, W. E. B., Suppression of the Slave Trade, New York, 1804.

Olmsted, F. L., A Journey in the Seaboard Slave States, 1853-54, New York, 1904.

Schwab, J. C., The Confederate States of America, Now York, 1904.

Eckenrode, H. J., The Political Fistory of Virginia during the Reconstruction, Johns Hopkins Press.

Documents Relating to Reconstruction, edited by W. L. Fleming, Morgantown, W. Va.

Bassett, J. 8., Slavery in the State of North Carolina, Johns Eop* kins Press.

$k$ 